\title{
Catena linking of landscape-geochemical processes and reconstruction of pedosedimentogenesis: A case study of defensive constructions of the mid- 17th century, South Russia
}

\author{
F.N. Lisetskii ${ }^{\mathrm{a}, *}$, V.I. Pichura ${ }^{\mathrm{b}}$ \\ ${ }^{a}$ Institute of Earth Sciences, Belgorod National Research University, Belgorod 308015, Russian Federation \\ ${ }^{\mathrm{b}}$ Kherson State Agrarian University, Kherson 73006, Ukraine
}

\section{A R T I C L E I N F O}

\section{Keywords:}

Pedotopocatena

Erosion-accumulative processes

Migration of elements

Pedosediments

Humus state

Rampart-ditch structure

\begin{abstract}
A B S T R A C T
The 'catena concept', along with previously proposed meanings of this term, has recently acquired a soil evolutionary content. The prospects of wider special and chronological study of dated pedotopocatenas include the possibility of a more detailed analysis of the mutual dependence of soil-geomorphological relationships through distinguishing relatively homogeneous climatic stages of pedogenesis and denudation. With this purpose, the present study comprised earthen defensive constructions, which, within the 'rampart/ditch' system, combine erosive, trans-accumulative catenas and accumulators of pedolithosediments. The goal was to develop a system of the most information-rich pedogenetic indicators to reconstruct the dynamics of erosion-accumulative processes on the basis of dated earthen defensive constructions of a historical period (using the example of a frontier rampart within a ditch from the mid-17th century). Soil samples were collected within the limits of the erosion and trans-accumulative catenas, as well as in the closing alignment of the ditch (over the vertical profile in eight strata of pedosediments of up to $1 \mathrm{~m}$ high). The granulometric composition, concentration of macroelements and trace elements (25 metals and oxides) in soils and in particles with sizes $<1 \mathrm{~mm}$, and the fractional composition of the humus were analysed in soil samples taken from different points in the catena and along the profile of the pedosediments. For the reconstruction of the humidity conditions over 3.5 centuries based on dendrochronological data, the cross-relation approach was applied. This allowed us to represent the chronostratigraphy of pedosediments as stages differing in the rate of accumulation processes. The system of soil indicators in pedosediments including the percentage of particles $0.001-0.005 \mathrm{~mm}$ and $>0.01 \mathrm{~mm}$ in size, the content of organic carbon and its qualitative composition, the sum of the elements accumulated in the soil ( $\mathrm{P}, \mathrm{Ca}, \mathrm{K}, \mathrm{Mg}$, $\mathrm{Mn}, \mathrm{Cu}$ ), as well as the geochemical ratios which reflect the processes of leaching, can serve as palaeogeographic tracers of the climatic variability at the level of intra-secular changes under forest-steppe conditions. The history of the formation of pedosediments over 3.5 centuries in the forest-steppe zone of Eastern Europe comprises two wet periods (1890-1935, 1976-2013) when the average annual rates of pedosedimentogenesis were similar (2.80-2.85 $\left.\mathrm{mm} \mathrm{yr}^{-1}\right)$ and two periods of geomorphological 'lull' and a xeromorphic climatic condition span (1821-1890 and 1666-1741). These periods correspond to diminution of the average rate of accumulation of sediments down to $2.47 \mathrm{~mm} \mathrm{yr}^{-1}$. The results of the present study suggest the need for purposeful research and wide inclusion of dated sites of the anthropogenic relief formation with flow-geochemical series over the topographic gradient into studies of soil-geomorphologic interrelations and calibration of mathematic models of natural processes using on-site data.
\end{abstract}

\section{Introduction}

Integration of soil and geomorphological studies allows to investigate a wide range of problems such as the development of chronosequences, a relief-related zonality of soils (Labaz et al., 2018), soils as indicators of landscape stability, soils as indicators of climate change, soils as indicators of erosion and deposition processes (Dixon, 2013; González-Arqueros et al., 2017; Vanwalleghem et al., 2013). Topographic features are a key soil-forming factor at the landscape level, which has received a special attention in connection with the soil

\footnotetext{
* Corresponding author.

E-mail address: liset@bsu.edu.ru (F.N. Lisetskii).
} 
catena concept (Gerrard, 1981, Bockheim et al., 2005).

Along the catena gradient, the majority of abiotic factors are naturally altered, in the first hand humidity and temperature of the air and soil, concentration and character of the movement of chemical elements and compounds in the soil. The determined sequence of soils along the hillslope gradient is defined by the changes of filtration, lateral transportation of the substance and erosion-accumulative processes on the surface and/or intra-soil transportation of the material. In the modern climate of the semiarid regions, the conditions of moistening, and within the catenas also conditions of the latter's redistribution, are among the defining factors of the formation of a soil-vegetation cover. This is why a considerable interest emerged for studies of the effects of lateral redistribution of soil moisture along the hillslope gradient (Hwang et al., 2009; Scarciglia et al., 2012; Schaetzl, 2013; Tetzlaff et al., 2014).

The catenary approach gives a possibility to represent the vector structure of dynamic genetic systems of hillslope landscapes. This is such a type of functioning, which is determined by the process of transportation of substance by lithodynamic and geochemical flows (Bevz, 2004). An erosion catena is the phenomenon where erosion and accumulation of the deposits in the upper and lower sections of a hillslope, respectively, result in deviation from the homogeneity of a soil cover (Ollier, 1976; Cohen et al., 2009; Kenderessy and Lieskovský, 2014). Soils, in particular slope soils, are characterized by anisotropy so that studies of pedotopocatenas allow us to combine organically the vertical-profile and geomorphologic peculiarities of the soil cover within a three-dimensional integral notion. In this connection, studies of erosion catenas are helpful in evaluation not only of the rate of the summary effects of water erosion and pedogenesis, but of the rate of each of them separately (Lisetsky and Polovinko, 2012).

Topography is one of the most important factors influencing the runoff and, correspondingly, the evolution of other landscape components such as soil catenas or soil cover patterns (Wolf et al., 2009) and successive series of vegetation along the topographic gradient (Hwang et al., 2009). Studies of vegetation patterns along the vertical gradient have shown that in their formation, microtopography determining the migration of soil moisture and salinity is of great importance (Deák et al., 2014). The structure of a soil cover is determined by realization of a number of major regularities of the soil geography including the lithogenic differentiation, lateral geochemical links between its components, as well as the historical-chronological diversity of the soil cover (Dyakonov et al., 2012; Gennadiev and Smirnova, 2012). The position within the landscape, hypsometric levels along the gradient and the lateral constituent of the migration processes represent the factors regulating the landscape evolution (Phillips, 2009).

Catena is a landscape unit in mapping the structure of soil cover (Fridland, 1974; Richter and Burras, 2017). As a natural body and a space-time and sign-image model, a transect-catena has properties of a mapping model (Ustinov, 2001; Murphy et al., 2011) promising for a computer simulation (Florinsky et al., 2002; Gabriela et al., 2005).

Since catena does not represent only a topographic series of soils and landscapes but also is a reflection of all the soil and hillslope phenomena and processes (Kasimov and Gennadiev, 2008), during an ecological evaluation of landscapes, an additional consideration is needed of the indicators characterizing geochemical transformations in the migration flows and in the depositing mediums (Avessalomova, 2009).

The studies of catenas become ever more interdisciplinary. In the first hand, it is important to obtain the physicochemical and mineralogical characteristics of the soil: aggregate stability (Bulygin and Lisetskiy, 1992; Cantón et al., 2009; Dyakonov et al., 2012), primary mineralogical and soil texture characteristics (Atanassova et al., 2009), content of clay and the clay/silt ratio (Roquero et al., 2015; Vanwalleghem et al., 2013), contents of sand and clay loam (Malinowska and Ceglińska, 2011). These results would be considerably supplemented by the data on the topographic distribution of the total organic carbon (Atanassova et al., 2009; Prikhod'ko et al., 2013) including the differences in its composition (Dergacheva et al., 2010), as well as the conduct of particular chemical elements explored, using as tracers e.g. chromites (Garnier et al., 2009), potassium forms (Amoakwah and Frimpong, 2013), Zr, and pedogenic crystalline Fe oxides (Yoo et al., 2011). Recently, ever more numerous studies in the geochemistry of landscapes are focused on the conduct of the complex of chemical elements (Kachinsky and Gennadiev, 2010) and, in particular, of the mobile elements (Ca, Na, Mg, Sr, U) (Pasquini et al., 2017) and available $\mathrm{Ca}, \mathrm{Mg}, \mathrm{K}, \mathrm{P}$ and $\mathrm{NH}_{4}$ (Murphy et al., 2011). Within this approach, the use of different elemental ratios and chemical indices becomes fairly helpful (Alekseev et al., 2018; Pasquini et al., 2017).

The notion of catena initially focused on the soil geomorphologic relations (Milne, 1935; Gerrard, 1981), with time, has expanded essentially in the soil hydrological (Jacobs et al., 2009), soil-geochemical (Glazovskaja, 1999; Gennadiev and Kasimov, 2004), soil-cartographic (Milne, 1935; Fridland, 1974; Richter and Burras, 2017) aspects. Moreover, what is of importance for the present study, the 'catena concept' received a soil-evolution content (Lisetskii, 1999; Henkner et al., 2017).

Since the absolute age of the soil cover can be determined for artificial geomorphologic surfaces, the possibility arises to evaluate quantitatively the influence of the locations and microlandscape conditions onto the rates of pedogenic processes. Heterochronous pedotopocatenas are more preferable in comparison with full-aged (Holocene) catenas because of the possibility of a stricter analysis of the interdependence of the soil-geomorphic relations through identification of relatively uniform climatic stages of soil-formation and denudation. In this connection, it is helpful to pay attention to such objects of studies as fortification installations of the historical period which in the system 'earthen rampart/ditch' combine erosion catenas and geomorphologic 'traps' (moats, ditches). These objects present on-location models enabling us to trace long-term (n-100 years) and stable manifestations of natural processes, associations of chemical elements within particular geomorphologic niches, peculiarities of geochemical migration in landscapes with a known zero-moment

The objects under study where the members of chronoseries are represented not by particular soils but by combinations of their types corresponding to different forms of relief can be called chronoseries of pedotopocatenas. During studies of stages of the formation of pedosediments, archaeological and radiocarbon, dating is used (Pustovoytov et al., 2011). However, concerning historical sites these processes can be evaluated more precisely (Bartz et al., 2017; Royall and Kennedy, 2016; Zemlyanitsky, 1949; Zolotareva et al., 2012; Wei et al., 2016) although for shorter time spans.

Results of archaeological investigations of old defensive structures (such as earthen ramparts and ditches) form a general notion of the morphological structure of soils of different periods in the stratigraphic aspect (Yermolin, 2012; Kozlenko, 2015; Maslennikov, 2003; Zaitsev, 2017) although without a consideration of the relations between newly formed soils and the peculiarities of the relief. In particular, this approach was employed in studies of defensive structures built since the first third of the 3rd century BCE (Maslennikov, 2003) including the 1st century BCE - 3rd century CE (Bujskikh, 1991). Chronoseries of the soils in millennium-aged catenas including the Trajan's Walls were comprehensively analysed using soil methods in the forest-steppe of Ukraine (Dmitruk et al., 2008) and steppe zone of Moldova (Lisetskii et al., 2013). The features of the pedotopocatenas at ramparts aged several centuries were investigated in different climatic conditions (Chichagov, 2005; Dmytruk et al., 2014; Zemlyanitsky, 1949; Zolotareva et al., 2012). Plant cover (Deák et al., 2017; SudnikWójcikowska and Moysiyenko, 2008) and pedotopocatenas (Gennadiev, 1984; Zemlyanitsky, 1949) including the soil-plant cover (Lisetskii et al., 2016) were studied at barrows.

Deluvial deposits can serve as geoarchives of the past human impacts onto the terrestrial environment (Henkner et al., 2017). If we 
know for a pedotopocatena the starting date of the formation of the sediments, then new possibilities arise in studies of the dynamics of the soil-geomorphologic processes and evaluation of their rates. Integration of archaeopedology and chronostratigraphy is especially effective as combining stratigraphic, sedimentological and micromorphological studies in order to reconstruct the complex processes of the site formation (Henkner et al., 2017; Linstädter et al., 2016).

Pedosedimentological studies conducted in different climatic conditions have enabled to obtain geochemical characteristics of suspended sediments (Campodonico et al., 2016; Han et al., 2017; Bianchini et al., 2019) including contents of heavy metals in surface sediments (Dolgikh, 2011; Xu et al., 2018; Wang et al., 2015a, 2015b). The rates of formation of stratozems (stratified aggraded soils formed due to accumulation of eroded sediments) can be calculated using the caesium137 isotope as a chronomarker (Golosov et al., 2017; Olson et al., 2013; Walling et al., 2000) or the use of spherical magnetic particles for evaluation of the rates of redistribution of alluvia (Gennadiev et al., 2013). There is a great information potential in the application of interdisciplinary methods in sedimentation studies, particularly those based on the data of field explorations and mathematic models (Zhidkin et al., 2015) and dendrochronology (Copini et al., 2015; Šilhán et al., 2016; Remy et al., 2018).

Thus, the combined exploration of erosion catenas and pedosediments under particular landscape conditions using pedogenic indicators allows us to establish the dynamics of erosion-accumulative processes. In similar studies, it is effective to use earthen defensive constructions as on-location models.

The present study aimed to develop a system of using the most information-rich pedogenic indicators to reconstruct the dynamics of erosion-accumulative processes on the basis of the dated earthen defensive installations of the historic period (using the example of a frontier rampart within a ditch from the mid-17th century). The fulfilment of this object required solutions to the following related tasks: (1) diagnosis of the processes of mechanic and aqueous migration in erosion trans-eluvial catenas and accumulation in pedosediments over 367 years of the defensive construction; (2) substantiation of the key physicochemical indicators including the composition of organic carbon for the chronostratigraphy of pedosediments; (3) development of a method of evaluating the rate and climatic stages of the accumulation of pedosediments using reconstruction of the conditions of moistening through a reference dendrochronoseries.

\section{Materials and methods}

\subsection{The area under studies}

The area under study is located in the western part of Belgorod Oblast (Russia). By the mid-17th century, a defensive line of about $800 \mathrm{~km}$ long - 'Belgorod Line' (Fig. 1) - had been built along the foreststeppe edge of the Russian state in order to prevent raids of the nomads from the southern steppe ('Dzike Pole ou Campagnes Desertes et Inhabitées' (Sanson brothers map 1674)). This defensive frontier was constructed in 1635-1658 and consisted of 28 fortresses. In the territory of what is now known as Belgorod Oblast, six significant townfortresses were arranged along this line (over $425 \mathrm{~km}$ ) and many ramparts and ditches were constructed. The Karpov section of the Belgorod Line was $24 \mathrm{~km}$ long and connected the town-fortresses of Karpov and Bolkhovets (1646). According to historical evidence, this was 'on the Crimean side via the valley of the Vorskla River, in the Karpov ostrog (fortress), an earthen embankment with nine small forts was built over 5 versts and $63^{1 / 4}$ sazhens [i.e. $5.47 \mathrm{~km}$ long - Authors]' (Istoricheskaya..., 1913, p. 314). The defences were under construction from August until September 15, 1646. Afterwards (three decades later) these fortifications lost their strategic significance. In statistic reports from the 19th century, Karpov is already called a 'former town'.

Results of a large-scale topographic survey from 1955, demonstrate that, in that period, the defensive structures with the general direction from NW to SE were $4475 \mathrm{~m}$ long. Only a fragment of this fortification system (earthen foundation of a tower and the rampart adjoining it) has survived to the present day. We explored this excellently preserved fragment of a $490 \mathrm{~m}$ long defensive line with a well-preserved topographic profile (from the top of the rampart to the bottom of the defensive ditch) (Fig. 1).

The defensive construction under study is situated on a watershed hillslope with an absolute heights of $190-200 \mathrm{~m}$. Initially, it was a rampart up to $3.2 \mathrm{~m}$ high and a ditch up to $4.3 \mathrm{~m}$ wide and $1 \mathrm{~m}$ deep (Shatokhin, 1991). Undoubtedly, throughout the entire period, the pedotopocatena remained under steppe conditions although there were forests in the valleys. Now, a sagebrush-feather grass association dominates here with increased mesophytization of the phytocenoses in the lower parts of the slopes. The basic soils are silt loam typical Chernozem (mollic Chernozem (FAO World, 1998)). Within the defensive structure, the erosion catena, from the top to the foot of the rampart with an average slope of $S=28^{\circ}$ and the transect-catena along the bottom of the ditch (trans-accumulative catena), as well as the vertical profile of the pedosediments in the closing alignment of the ditch, were the objects of study. Selection of the soil samples was conducted at three positions of the microcatena within the area of the rampart slope (points 1,2 and 3) and along the thalweg of the defensive ditch at $270 \mathrm{~m}$ (point 4) and farther at $160.7 \mathrm{~m}$ (point 5) up to the transition of the ditch into a ravine (Table 1). In addition, soil samples were taken in the closing alignment of the ditch along the vertical profile of pedosediments up to $1 \mathrm{~m}$ thick in eight strata, which were discernible according to their macromorphological characteristics and soil colour.

The forest-steppe and steppe landscapes form a zone of the most intensive water-erosion processes. During the last decades, the latter have been studied both for identification of spatial-temporal regularities and in order to obtain quantitative evaluations of erosion-accumulative processes (Lisetskii et al., 2012). A summarization of the data throughout Moldova, Ukraine and Russia (Surmach, 1992; Nour, 2001) demonstrated that, in agricultural landscapes, the presence of weak, mean or strong erosion depends on the average length of the slope $300-500,500-700$ and $700-1000 \mathrm{~m}$ respectively and weak, mean and strong erosion of the soils arise on slopes of up to 3 , from 2.5 to 4 and from 3 to $5^{\circ}$ respectively. However, more distinctly the geomorphologic preconditions of erosion can be evaluated using the relief function (LS) which accounts for differing contribution of the length (L) and slope (S) to the rate of erosion. As established previously via comparison of several equations of LS applied to pedotopocatenas (Lisetsky and Polovinko, 2012), three types of formula have proved to be accurate for the calculation of LS for short slopes (Wischmeier and Smith, 1978; Morgan, 1979; Stone and Hilborn, 2000). These formulas have demonstrated their effectiveness when used for the evaluation of the results of the combined erosion and pedogenesis on short slopes.

\subsection{Methods}

Data on the length (L) and steepness (S) allowed us to calculate the values of the relief function (LS) according to the formula (Morgan, 1979).

The granulometric analysis was conducted using a laser analyser of the size of the particles Analysette 22 MicroTec (Fritsch GmbH). Sample preparation of dry soil was carried out by sieving through a mesh size of $0.25 \mathrm{~mm}$. The preparation of soil samples for chemical analyses was fulfilled in two variants: reduction of the entire weighted sample of the soil to a powdered state and applying of this procedure only to structural units $<1 \mathrm{~mm}$ in size. Through the ratio of the content of each chemical element $(1,2, \ldots$ i) in particles measuring $<1 \mathrm{~mm}$ and over for the entire soil sample, an indicator, the coefficient of selectivity (Kci), was calculated. Chemical analyses of soils included the following the assessment of the Corg after Tyurin and $\mathrm{CO}_{2}$ in carbonates by 

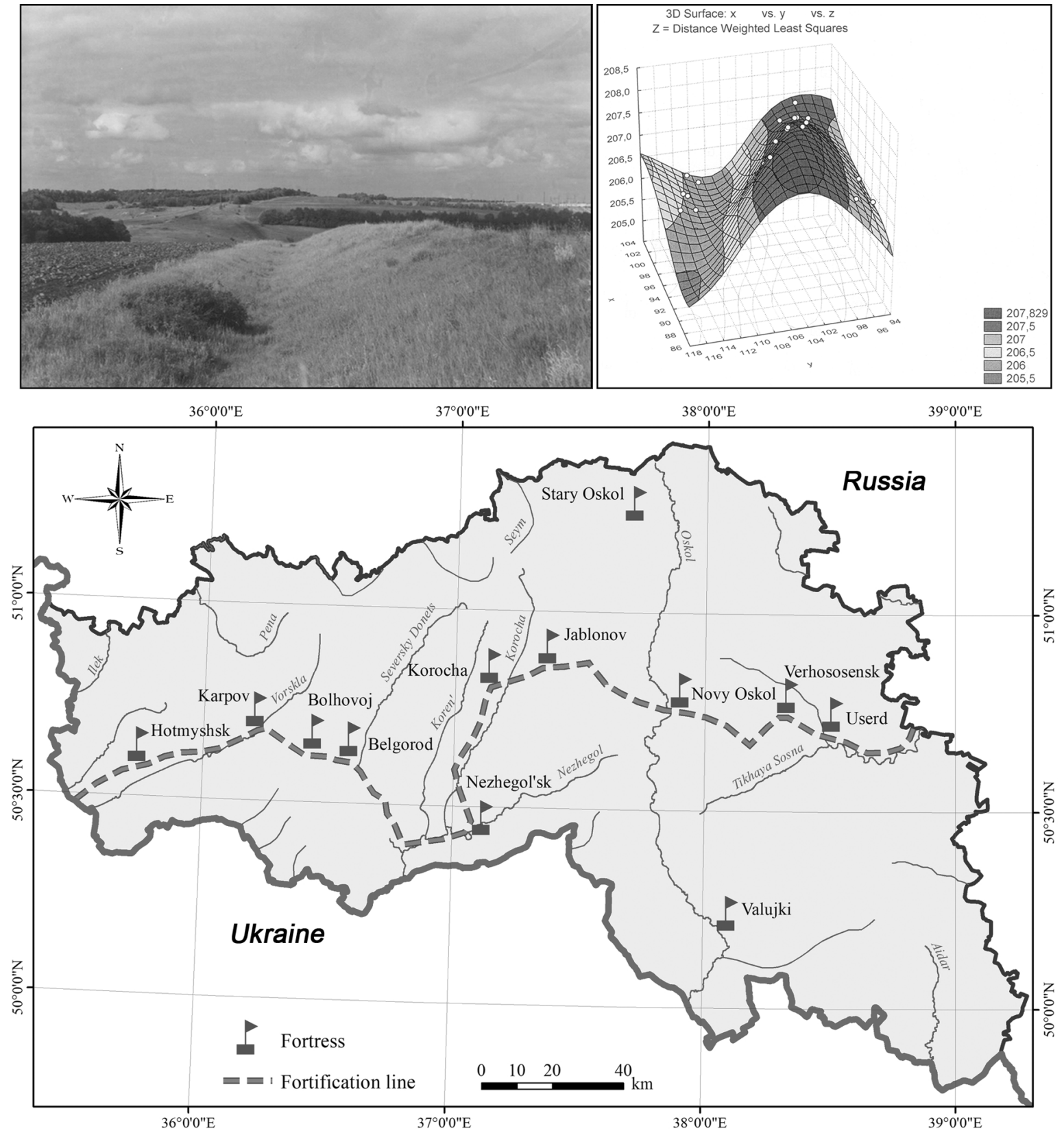

Fig. 1. Belgorod Line in the modern borders of Belgorod Oblast and the Karpov rampart with ditch.

acidometry. The $\mathrm{pH}$ values $\left(\mathrm{H}_{2} \mathrm{O}\right)$ were determined by a potentiometric method ( $\mathrm{pH}$ meter Sartorius Basic Meter PB-11). Total nitrogen (N) was estimated by Kjeldahl's procedure. The group and fractional analysis of humus was fulfilled by Tyurin's method modified by Ponomareva and
Plotnikova. After determination of the fractional composition of humus (humic acid (HA) and fulvic acid (FA), respectively), the index of the extent of mobility of the humic substances was calculated (based on contents of seven fractions) - Dm (Kononova and Alexandrova, 1973).

Table 1

Characteristics of the objects under study on the microslope of the rampart and in the thalweg of the ditch at the Karpov section of the Belgorod defensive line of 1646.

\begin{tabular}{|c|c|c|c|c|c|c|c|c|}
\hline Point no. & Coordinates (latitude; longitude) & Position & \multicolumn{2}{|c|}{ Length (m) } & LS & $\mathrm{PPC}^{*}(\%)$ & $\mathrm{H}^{* *}(\mathrm{~cm})$ & Bulk density $(0-10 \mathrm{~cm})\left(\mathrm{g} \mathrm{cm}^{-3}\right)$ \\
\hline \multicolumn{9}{|c|}{ Catena on the slope of the rampart } \\
\hline 1 & $50^{\circ} 39^{\prime} 51.9^{\prime \prime} \mathrm{N} ; 36^{\circ} 23^{\prime} 06^{\prime \prime} \mathrm{E}$ & Top & 0 & - & 0 & 80 & 40 & 0.80 \\
\hline 2 & $50^{\circ} 39^{\prime} 51.8^{\prime \prime} \mathrm{N} ; 36^{\circ} 23^{\prime} 05.9^{\prime \prime} \mathrm{E}$ & Middle of the slope & 4.5 & - & 3.64 & 70 & 30 & 0.99 \\
\hline 3 & $50^{\circ} 39^{\prime} 51.6^{\prime \prime} \mathrm{N} ; 36^{\circ} 23^{\prime} 05.8^{\prime \prime} \mathrm{E}$ & Foot & 9.1 & 0 & 5.34 & 90 & 70 & 0.98 \\
\hline \multicolumn{9}{|c|}{ Transect-catena in the bottom of the ditch } \\
\hline 4 & $50^{\circ} 39^{\prime} 46.4^{\prime \prime} \mathrm{N} ; 36^{\circ} 23^{\prime} 16.9^{\prime \prime} \mathrm{E}$ & Middle of the ditch & - & 270 & 1.02 & 100 & 80 & 0.89 \\
\hline 5 & $50^{\circ} 39^{\prime} 43.3^{\prime \prime} \mathrm{N} ; 36^{\circ} 23^{\prime} 23.5^{\prime \prime} \mathrm{E}$ & Mouth of the ditch & - & 431 & 3.42 & 100 & 77 & 0.89 \\
\hline
\end{tabular}

Note: *PPC is plant projective cover; ${ }^{* *} \mathrm{H}$ is average height of the grass. 
The calculation was fulfilled by the formula: $\mathrm{Dm}=(\mathrm{HA}-1+\mathrm{FA}-1+\mathrm{FA}-$ 1a)/(HA-2 + HA-3 + FA-2 + FA-3), where HA-1 is the free fraction that associated with mobile sesquioxides; FA-1 is the aggressive fraction; FA-1a is the fraction associated with HA-1; HA-2 is the calciumbound fraction; HA-3 is the fraction associated with the clay fraction and stable sesquioxides; FA-2 is the HA-2 fraction; and FA- 3 is the fraction associated with HA-3.

A wavelength-dispersion X-ray fluorescence spectrometer (Spectroscan Max-GV) was used to determine the contents of chemical elements. The concentrations of macroelements and trace elements in soils ( 25 metals and oxides) were determined by measuring the fractions of metal mass and oxides in powdered samples. The X-ray fluorescence analysis method showed its effectiveness in obtaining sedimentological characteristics (Hubert-Ferrari et al., 2017). Using the determinations of the bulk composition of soils and sediments, the most informative geochemical indicators were calculated: $\mathrm{CaO} / \mathrm{TiO}_{2}, \mathrm{CaO} /$ $\mathrm{ZrO}_{2}, \mathrm{Si} /(\mathrm{Al}+\mathrm{Fe}+\mathrm{Mn}),(\mathrm{CaO}+\mathrm{MgO}) / \mathrm{Al}_{2} \mathrm{O}_{3}, \mathrm{SiO}_{2} / \mathrm{Al}_{2} \mathrm{O}_{3}$, the sum of the elements accumulated in the soil $(\mathrm{P}, \mathrm{Ca}, \mathrm{K}, \mathrm{Mg}, \mathrm{Mn}$ and $\mathrm{Cu}$ ) (Perel'man, 1975) $-\mathrm{S}_{\mathrm{A}}$. Accepting Liu's proposition (Liu et al., 2009) concerning the eluviation coefficient (Ke), the modified variant of the formula included the basic oxides: $\mathrm{Ke}=\left(\mathrm{SiO}_{2} /\right.$ $\left.\left(\mathrm{MnO}+\mathrm{CaO}+\mathrm{K}_{2} \mathrm{O}+\mathrm{MgO}+\mathrm{Na}_{2} \mathrm{O}\right)\right)$. A geochemical classification of the elements in terms of the peculiarity of their migration was employed by A.I. Perel'man (1975) enabling to evaluate the landscape characteristics of the association of mobile ( $\mathrm{Ca}, \mathrm{Na}, \mathrm{Mg}$ and $\mathrm{Sr}$ ) and weakly mobile (K, Ba and Rb) elements $-\Sigma$ mob. Colours (dry/moist) were described using the Munsell-System (Munsell color, 2000).

Grouping of the strata of pedosediments was conducted by the method of cluster analysis hierarchic classification (unification by Ward's method) based on the most informative indices normalized through mean-square deviation.

\subsection{Reconstruction of climate from dendrochronological evidence}

Parameters of the climatic norm were obtained from the closest meteorological station (Belgorod): the mean annual precipitation was $553 \mathrm{~mm}$ including $67 \%$ for the warm period. The mean annual temperature was $+6.6^{\circ} \mathrm{C}$. The maximum height of the snow cover was $17-20 \mathrm{~cm}$, but thawing occurred during all of the winter months. The average values of the flow layer from thaw waters in this region was $48 \mathrm{~mm}$ (Surmach, 1992). In some years, the soil frost penetration depth reached 10 to $116 \mathrm{~cm}$. According to observations from 1941 to 2017, a considerable variation in the mean annual precipitation is notable (variation coefficient (V) equals to $21 \%$ ).

For reconstruction of the conditions of humidity, previously, the longest series of observations of precipitation (since 1900) was obtained from the main meteorological station in the region, Bogoroditskoye-Fenino, and dendrochronological data were obtained from the regional database (Lisetskii et al., 2007). In order to eliminate the problems caused by cross-dating of core samples from different sites, we selected a reference point of the longest age from the database. This was a saw cut of petiolate oak aged 224 years, which was obtained in 1968 within the frame of the International Biological Program (the sample is kept in the museum of the environment of the reserve 'Belogorye'). The oak tree under consideration grew in an oak grove 250-300 years old in the southeast of the forest reserve 'Forest on the Vorskla' (29 km from the Karpov rampart).

In the reconstruction of the annual total precipitation of the period of instrumental observations (1720-1899), the cross-correlation approach was used in order to define the relation of the response of many years of radial growth of the oak tree under conditions of humidity. The synchronism of the rhythms of precipitation and tree-ring growth was investigated using difference integral curves of modular coefficients. The cyclic constituents of the dendro-chronoseries and precipitations were studied by means of Fourier analysis. Filtration of the noises in the rhythms of many years was conducted using the $4253 \mathrm{H}$ filter; the filtration method enabled us to obtain a smoothed series, simultaneously retaining the main rhythmic characteristics of the original one. For the treatment, the licensed software STATISTICA Advanced + QC for Windows v.10 Ru and STATISTICA Automated Neural Networks for Windows v.10 Ru were employed.

\section{Results and discussion}

\subsection{Characteristics of the defensive construction}

An earthen rampart and a ditch are elements that are functionally tied to defensive structures. They were profiled so that their defenders could shoot at the bottom of the ditch from the top of the rampart (Bujskikh, 1991). Through a transect (geodesic profile) which we started from north-east to south-west across the system 'rampart/ditch' (Table 1) present-day morphometric parameters of the defensive construction were defined: the width of the rampart was $8 \mathrm{~m}$ at its foundation, the total width of the rampart within the ditch was $16.5 \mathrm{~m}$, the relative height of the rampart over the thalweg level of the ditch was $3 \mathrm{~m}$, the width of the ditch on the surface was $6 \mathrm{~m}$, and the width of its bottom, $-1.8 \mathrm{~m}$, represented the depth of the ditch relative to its external edge $-0.92 \mathrm{~m}$. The average steepness of the slope from the crest to the bottom of the ditch was $17.6^{\circ}(31 \%)$. The ratio of the internal slope of the rampart was 2.7 and that of the external slope was 3 .

The values of topographic factors (LS) on an erosion catena (3.6-5.3) are diagnostic of a high erosion potential of the relief, primarily because at considerable inclinations on an erosion catena, as in our case, the dependence of the soil washout on the slope angle is proportional to the sinus of the slope angle (Lisetskii et al., 2012). In the area of a trans-accumulative catena, due to a gradual increase of the slope, the LS value increases gradually and, judging from the soil thickness, accumulation of sediments was already taking place at the middle of the length of the ditch, because the turbidity of the flow equalled to or exceeded the turbidity corresponding to its transporting capacity.

\subsection{Erosion catena}

After the end of their use, defensive ramparts are transformed through consecutive stages (geomorphologic profiles) which may be called trajectories of relaxation (Thornes and Brunsden, 1977). The soil cover along the topographic gradient is an important regulator of this process. The thickness of the newly formed horizon of humus changes along the slope from 10 to $35 \mathrm{~cm}$. Using the model of the formation of a humic horizon of soils over time, which was constructed with empirical data on the conditions of forest-steppe (Goleusov and Lisetskii, 2008), it was calculated that the thickness of the humus in an automorphic position in soils aged 367 years usually equals $17.6-18.3 \mathrm{~cm}$. On the top of the defensive rampart under study (at point 1 near the edge), the newly formed soil is not as thick $(\mathrm{A}+\mathrm{AB}=14+6 \mathrm{~cm})$ as at the trans-accumulative position of the rampart (point 2): $A+A B=26.5+17.5 \mathrm{~cm}$.

The added substratum of the rampart consisted of a mixture of the soil material and loess-like loam. This substratum became the parent rock for the newly formed soils. In terms of their granulometric composition, all the soils under study were of a silty clay type (the percentage of particles sized $<0.01 \mathrm{~mm}$ is from 64 to $70 \%$ ) with an average clay content $(<2 \mu \mathrm{m})$ from $16.7 \%$ (catena on the slope of the rampart) to $18.0 \%$ (transect-catena) (Table 2). Along the catena, the percentage of the finest particles $(<0.0005 \mathrm{~mm})$ regularly decreases the granulometric composition of the soils in the layer of $0-10 \mathrm{~cm}$. The maximum clayiness of the granulometric composition (with the sum of particles $<0.001 \mathrm{~mm}$ ) is observable in the slope soil (point 2). This must have been favourable for the fixation of organic substances. Indeed, within erosion catenas, the soil of the micro-slope is marked with the highest content of humus (Table 3) and, simultaneously, with the greatest extent of humification (Cha/Cfa is 4.4). However, this soil is 
Table 2

Content of particles, $\mathrm{mm}(\%)$.

\begin{tabular}{|c|c|c|c|c|c|c|c|}
\hline Point no. & Layer, cm & $0.25-0.05$ & $0.05-0.01$ & $0.01-0.005$ & $0.005-0.001$ & $0.001-0.0005$ & $<0.0005$ \\
\hline \multicolumn{8}{|c|}{ Catena on the slope of the rampart } \\
\hline \multirow[t]{3}{*}{1} & $0-14$ & 0.00 & 33.67 & 36.24 & 24.42 & 4.31 & 1.37 \\
\hline & $14-20$ & 0.011 & 31.27 & 34.87 & 27.97 & 4.71 & 1.17 \\
\hline & $20-30$ & 0.011 & 32.20 & 33.92 & 26.83 & 5.25 & 1.79 \\
\hline \multirow[t]{3}{*}{2} & $0-10$ & 0.00 & 30.61 & 34.21 & 29.19 & 4.77 & 1.23 \\
\hline & $10-20$ & 0.017 & 33.78 & 35.45 & 25.46 & 4.31 & 0.96 \\
\hline & $20-30$ & 0.00 & 36.36 & 35.22 & 22.16 & 4.65 & 1.61 \\
\hline \multirow[t]{3}{*}{3} & $0-10$ & 0.00 & 34.25 & 36.35 & 24.11 & 4.10 & 1.19 \\
\hline & $10-20$ & 0.00 & 35.27 & 36.72 & 22.31 & 4.05 & 1.66 \\
\hline & $20-30$ & 0.00 & 33.93 & 35.84 & 24.60 & 4.26 & 1.37 \\
\hline \multicolumn{8}{|c|}{ Transect-catena in the bottom of the ditch } \\
\hline \multirow[t]{3}{*}{4} & $0-10$ & 0.011 & 32.50 & 35.92 & 26.43 & 4.16 & 0.98 \\
\hline & $10-20$ & 0.00 & 32.13 & 35.35 & 26.95 & 4.48 & 1.09 \\
\hline & $20-30$ & 0.008 & 31.94 & 35.76 & 26.94 & 4.26 & 1.04 \\
\hline \multirow[t]{8}{*}{5} & $0-10$ & 0.007 & 31.47 & 35.45 & 27.59 & 4.35 & 1.13 \\
\hline & $10-20$ & 0.00 & 30.58 & 35.52 & 28.29 & 4.51 & 1.09 \\
\hline & $20-30$ & 0.00 & 31.21 & 35.32 & 27.85 & 4.46 & 1.16 \\
\hline & $30-50$ & 0.014 & 32.35 & 35.49 & 26.59 & 4.40 & 1.16 \\
\hline & $50-70$ & 0.00 & 30.17 & 35.25 & 28.89 & 4.58 & 1.11 \\
\hline & $70-90$ & 0.00 & 30.45 & 34.08 & 29.61 & 4.64 & 1.21 \\
\hline & $90-95$ & 0.00 & 30.38 & 34.11 & 29.75 & 4.56 & 1.19 \\
\hline & 95-100 & 0.00 & 29.84 & 34.04 & 30.21 & 4.72 & 1.18 \\
\hline
\end{tabular}

peculiar due to the minimum extent of mobility of the humic substances (in the two lower layers Dm is 0.08-0.09).

Significant changes in soil colour are noted in the profile of the pediments with a depth of $73 \mathrm{~cm}$ (dry) and $86 \mathrm{~cm}$ (wet) (Table 3).

Baseline geochemical data for soils (Points 1-4) and pedosediments (Point 5) are included in Table 4. The original soil, which in 1646 was used for the construction of the rampart (20-30 cm layer on the top of the rampart (point 1)), had values of Kci $>1$ for 11 chemical elements and its maximum average, as compared with the other soils studied. This allowed us to consider this soil as the basis for the evaluation of the results of soil-geochemical transformations in particular landscape situations.

The $\mathrm{pH}$ value in the soil correlated with the distribution of carbonates along the hillslope gradient: under study regularly decreases within the catena from 8.3 (in point 1 ) to 6.8 (in point 3 ). This feature is diagnostic of the differences in the relative ages of the geosystems: in the direction of the processes, the base of the catena grows more rapidly closer to the geosystem of a zonal (forest-steppe) type than the narrow top and the steep slope of the defensive rampart.

As demonstrated previously by studies of catenas at mounds (Lisetskii et al., 2016), for the formation of a definite type of vegetation association under the conditions of newly formed ecosystems, the chemical properties of the soils (contents of the total and labile humus and mobile elements of nutrition, carbonate content) are of utmost importance. Second place is held by the content of the trace elements; the third is held by macroelements. The history of chemical weathering to which the soils were subjected as well as the factors of concentration/depletion can be defined through the content of weakly mobile elements such as Ti or Zr (Fitze and Egli, 2000). Within the limits of the catena of the earthen rampart, the most intensive changes in the profiles of the soils were found on the top of the rampart: ratios $\mathrm{CaO} / \mathrm{TiO}_{2}$ and $\mathrm{CaO} / \mathrm{ZrO}_{2}$ differ 2.2-3 times (Table 4). Moreover the values of the

Table 3

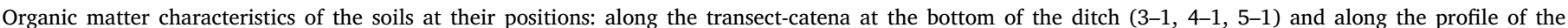
pedosediments $(5-2 \div 5-8)$.

\begin{tabular}{|c|c|c|c|c|c|c|c|c|c|c|c|c|}
\hline Soil no. & 1 & 2 & 3 & 4 & 5 & & & & & & & \\
\hline Layers, cm & $0-14$ & $0-10$ & $0-10$ & $0-10$ & $0-10$ & $10-20$ & $20-30$ & $30-50$ & $50-70$ & $70-90$ & $90-95$ & $95-100$ \\
\hline Colour dry & 10YR $3 / 1$ & $\begin{array}{l}\text { 10YR 3/ } \\
1.5\end{array}$ & 10YR $3 / 2$ & 10YR $3 / 2$ & $\begin{array}{l}\text { 10YR 3/ } \\
1.5\end{array}$ & $\begin{array}{l}\text { 10YR 3/ } \\
1.5\end{array}$ & 10YR $3 / 2$ & $\begin{array}{l}\text { 10YR 3/ } \\
2.5\end{array}$ & 10YR $3 / 2$ & 10YR $5 / 3$ & 10YR $5 / 3$ & 10YR $5 / 4$ \\
\hline Corg, \% & 3.38 & 3.24 & 3.74 & 3.94 & 3.52 & 2.78 & 2.39 & 2.34 & 2.00 & 1.70 & 1.34 & 1.09 \\
\hline $\mathrm{C}_{\mathrm{HA}}, \%$ in Corg & 33.08 & 36.42 & 37.70 & 32.92 & 30.40 & 32.30 & 33.48 & 39.84 & 32.90 & 29.18 & 34.03 & 23.66 \\
\hline $\mathrm{C}_{\mathrm{FA}}, \%$ in Corg & 14.79 & 11.73 & 16.41 & 12.70 & 26.14 & 16.47 & 17.00 & 11.47 & 13.80 & 14.06 & 25.00 & 28.07 \\
\hline $\mathrm{C}_{\mathrm{HA}} / \mathrm{C}_{\mathrm{FA}}$ & 2.2 & 3.1 & 2.3 & 2.6 & 1.2 & 1.9 & 1.9 & 3.4 & 2.4 & 2.1 & 1.4 & 0.8 \\
\hline Type of humus * & $\mathrm{PH}$ & & & & $\mathrm{FH}$ & $\mathrm{H}$ & & $\mathrm{PH}$ & & & $\mathrm{FH}$ & $\mathrm{HF}$ \\
\hline Humification degree $* *$ & high & & & & & & & & & medium & high & medium \\
\hline $\mathrm{HA}-1, \%$ in the sum of $\mathrm{HA}$ & 8.77 & 4.23 & 17.72 & 5.92 & 7.47 & 5.36 & 2.51 & 3.44 & 1.22 & 3.22 & 3.50 & 3.08 \\
\hline $\mathrm{HA}-2, \%$ in the sum HA & 66.96 & 72.03 & 65.25 & 67.69 & 45.79 & 63.48 & 71.24 & 57.93 & 71.43 & 68.54 & 61.42 & 42.65 \\
\hline HA- $3, \%$ in the sum HA & 24.11 & 23.73 & 17.02 & 26.15 & 46.74 & 31.18 & 26.25 & 38.63 & 27.36 & 28.24 & 35.09 & 54.27 \\
\hline Chumin, \% in Corg & 52.13 & 51.85 & 45.89 & 54.38 & 43.46 & 51.23 & 49.52 & 48.69 & 53.30 & 56.76 & 40.97 & 48.27 \\
\hline $\mathrm{Dm}$ & 0.21 & 0.21 & 0.44 & 0.31 & 0.19 & 0.17 & 0.11 & 0.10 & 0.22 & 0.13 & 0.10 & 0.15 \\
\hline $\mathrm{N}$ gross, \% & 0.31 & 0.22 & 0.18 & 0.25 & 0.18 & 0.20 & 0.20 & 0.13 & 0.13 & 0.11 & 0.13 & 0.09 \\
\hline $\begin{array}{l}\mathrm{C} / \mathrm{N} \\
\text { Humus enrichment in nitrogen } * * *\end{array}$ & $\begin{array}{l}10.9 \\
\text { medium }\end{array}$ & $\begin{array}{l}14.7 \\
\text { very low }\end{array}$ & 20.8 & 15.6 & 19.6 & $\begin{array}{l}13.9 \\
\text { low }\end{array}$ & 11.9 & $\begin{array}{l}18.0 \\
\text { very low }\end{array}$ & 15.4 & 15.5 & $\begin{array}{l}10.3 \\
\text { medium }\end{array}$ & $\begin{array}{l}12.1 \\
\text { low }\end{array}$ \\
\hline
\end{tabular}

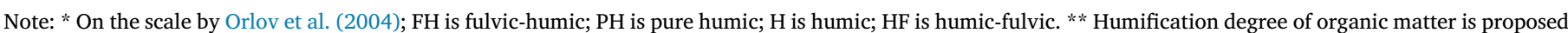

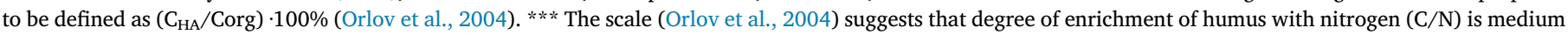
$(\mathrm{C} / \mathrm{N}$ is $8-11)$, low $(\mathrm{C} / \mathrm{N}$ is $11-14)$, and very low $(\mathrm{C} / \mathrm{N}$ is $>14)$. 
Table 4

The content of macroelements and trace elements in a soil catena and the pedosediments.

\begin{tabular}{|c|c|c|c|c|c|c|c|c|c|c|c|c|c|c|c|c|c|c|c|c|c|c|}
\hline \multirow[t]{3}{*}{ Point-layer no. } & \multicolumn{10}{|c|}{ Macroelements } & \multicolumn{12}{|c|}{ Trace elements } \\
\hline & $\mathrm{SiO}_{2}$ & $\mathrm{Al}_{2} \mathrm{O}_{3}$ & $\mathrm{CaO}$ & $\mathrm{Fe}$ & $\mathrm{TiO}_{2}$ & $\mathrm{~K}_{2} \mathrm{O}$ & $\mathrm{MgO}$ & $\mathrm{Na}$ & $\mathrm{P}_{2} \mathrm{O}_{5}$ & $\mathrm{MnO}$ & $\mathrm{Zr}$ & $\mathrm{Ba}$ & $\mathrm{Sr}$ & $\mathrm{V}$ & $\mathrm{Cr}$ & $\mathrm{Rb}$ & $\mathrm{Zn}$ & $\mathrm{Cu}$ & $\mathrm{Ni}$ & $\mathrm{Pb}$ & Co & As \\
\hline & $\%$ & & & & & & & & & & ppm & & & & & & & & & & & \\
\hline $1-1$ & 56.4 & 9.6 & 1.5 & 2.5 & 0.7 & 1.8 & 0.5 & 0.3 & 0.1 & 637.9 & 388.9 & 412.3 & 75.3 & 69.8 & 81.1 & 75.5 & 67.8 & 40.5 & 36.4 & 17.0 & 20.3 & 7.4 \\
\hline $1-2$ & 61.0 & 10.0 & 2.1 & 2.6 & 0.7 & 1.8 & 0.6 & 0.3 & 0.1 & 583.1 & 376.3 & 431.0 & 83.6 & 80.0 & 89.5 & 76.5 & 57.1 & 39.0 & 36.1 & 15.2 & 12.5 & 6.2 \\
\hline $1-3$ & 65.4 & 9.5 & 4.0 & 2.1 & 0.7 & 1.8 & 0.7 & 0.5 & 0.1 & 525.0 & 458.2 & 401.1 & 98.9 & 60.8 & 79.6 & 66.2 & 52.4 & 27.6 & 28.9 & 12.6 & 11.6 & 7.1 \\
\hline $2-1$ & 63.2 & 9.8 & 1.4 & 2.5 & 0.7 & 1.9 & 0.6 & 0.3 & 0.1 & 662.2 & 391.1 & 435.2 & 78.5 & 70.6 & 82.8 & 77.8 & 66.1 & 37.5 & 34.2 & 14.5 & 15.1 & 6.5 \\
\hline $2-2$ & 58.9 & 10.1 & 1.5 & 2.6 & 0.7 & 1.8 & 0.6 & 0.3 & 0.1 & 710.4 & 414.0 & 436.4 & 80.4 & 71.9 & 85.6 & 76.9 & 62.4 & 39.1 & 36.8 & 14.1 & 15.9 & 6.8 \\
\hline $2-3$ & 60.8 & 9.4 & 1.7 & 2.6 & 0.7 & 2.0 & 0.6 & 0.5 & 0.1 & 644.8 & 380.5 & 427.0 & 78.0 & 70.7 & 81.3 & 76.2 & 69.1 & 38.4 & 36.7 & 15.4 & 13.8 & 6.3 \\
\hline $3-1$ & 62.2 & 9.4 & 1.4 & 2.6 & 0.8 & 2.0 & 0.5 & 0.4 & 0.2 & 767.8 & 369.2 & 451.7 & 83.7 & 77.0 & 85.0 & 84.2 & 81.1 & 36.1 & 34.0 & 20.2 & 15.0 & 7.4 \\
\hline $3-2$ & 61.6 & 9.8 & 1.3 & 2.5 & 0.7 & 1.9 & 0.6 & 0.4 & 0.1 & 642.8 & 366.0 & 424.6 & 56.1 & 64.5 & 80.4 & 79.6 & 71.5 & 37.7 & 35.4 & 15.9 & 15.5 & 7.3 \\
\hline $3-3$ & 65.4 & 10.4 & 1.2 & 2.5 & 0.7 & 2.0 & 0.6 & 0.3 & 0.1 & 638.3 & 378.3 & 430.2 & 53.9 & 64.4 & 79.9 & 79.7 & 69.8 & 39.0 & 34.8 & 17.1 & 16.7 & 7.3 \\
\hline $4-1$ & 58.1 & 10.3 & 1.6 & 2.7 & 0.7 & 2.0 & 0.7 & 0.3 & 0.2 & 731.8 & 344.5 & 444.6 & 64.8 & 78.2 & 82.9 & 77.8 & 81.0 & 45.3 & 42.1 & 16.0 & 17.4 & 7.6 \\
\hline 4-2 & 62.2 & 11.0 & 1.4 & 2.8 & 0.7 & 2.0 & 0.7 & 0.4 & 0.1 & 678.2 & 393.4 & 463.2 & 62.4 & 84.6 & 84.0 & 78.5 & 69.5 & 41.8 & 39.3 & 16.3 & 14.6 & 7.5 \\
\hline $4-3$ & 62.7 & 10.8 & 1.5 & 2.8 & 0.8 & 2.0 & 0.7 & 0.3 & 0.1 & 709.1 & 388.7 & 453.0 & 56.5 & 80.8 & 86.6 & 76.7 & 69.5 & 44.7 & 41.4 & 17.7 & 14.4 & 7.6 \\
\hline 5-1 & 60.9 & 10.2 & 1.6 & 2.7 & 0.7 & 2.0 & 0.7 & 0.3 & 0.1 & 644.2 & 363.3 & 410.1 & 66.0 & 74.2 & 83.9 & 81.4 & 73.1 & 46.0 & 40.7 & 19.0 & 18.4 & 6.8 \\
\hline $5-2$ & 60.3 & 10.5 & 1.5 & 2.8 & 0.8 & 1.9 & 0.7 & 0.4 & 0.1 & 667.5 & 403.7 & 434.0 & 70.1 & 76.9 & 85.2 & 80.5 & 70.7 & 43.0 & 41.2 & 17.3 & 16.0 & 7.4 \\
\hline $5-3$ & 56.5 & 9.7 & 1.7 & 2.8 & 0.7 & 1.9 & 0.6 & 0.5 & 0.1 & 631.1 & 372.5 & 444.0 & 68.3 & 84.3 & 84.3 & 79.9 & 65.3 & 44.7 & 40.2 & 17.5 & 17.3 & 7.1 \\
\hline $5-4$ & 64.3 & 11.6 & 1.7 & 2.7 & 0.7 & 2.0 & 0.8 & 0.4 & 0.1 & 633.4 & 383.6 & 432.6 & 59.3 & 78.9 & 82.2 & 79.0 & 72.6 & 45.3 & 40.5 & 19.2 & 16.9 & 7.2 \\
\hline $5-5$ & 64.5 & 11.7 & 1.4 & 2.8 & 0.8 & 2.0 & 0.8 & 0.3 & 0.1 & 628.1 & 372.4 & 427.5 & 50.4 & 74.7 & 81.3 & 77.8 & 66.5 & 46.9 & 40.9 & 19.7 & 15.9 & 7.0 \\
\hline $5-6$ & 61.8 & 11.6 & 1.4 & 2.9 & 0.8 & 1.9 & 0.7 & 0.3 & 0.1 & 637.7 & 379.6 & 426.9 & 51.2 & 81.1 & 88.9 & 77.6 & 71.4 & 45.8 & 43.9 & 17.2 & 17.8 & 7.0 \\
\hline $5-7$ & 60.9 & 11.0 & 1.3 & 2.9 & 0.8 & 1.9 & 0.8 & 0.5 & 0.1 & 618.7 & 403.6 & 422.7 & 55.3 & 81.0 & 88.5 & 78.7 & 67.1 & 46.1 & 43.8 & 16.4 & 20.7 & 7.1 \\
\hline $5-8$ & 61.7 & 11.1 & 1.4 & 3.0 & 0.8 & 1.9 & 0.8 & 0.3 & 0.1 & 598.5 & 400.7 & 426.5 & 60.8 & 83.8 & 105.7 & 78.6 & 67.3 & 44.6 & 44.1 & 18.8 & 18.4 & 6.9 \\
\hline
\end{tabular}

indices $\mathrm{Si} /(\mathrm{Al}+\mathrm{Fe}+\mathrm{Mn}),(\mathrm{CaO}+\mathrm{MgO}) / \mathrm{Al}_{2} \mathrm{O}_{3}, \quad \mathrm{SiO}_{2} / \mathrm{Al}_{2} \mathrm{O}_{3}, \quad \mathrm{SiO}_{2} /$ $\mathrm{Fe}_{2} \mathrm{O}_{3}$ increase with the depth while $\mathrm{Ke}$, the sum of the elements accumulated in the soil or the ratio $\mathrm{K}_{2} \mathrm{O} / \mathrm{SiO}_{2}$, is reduced. This geomorphologic niche (the near-edge part of the microslope) is characterised by the utmost dynamism of the syngenetic processes of denudation and soil formation.

\subsection{Trans-accumulative catena}

The soil record, archive or soil memory (in other words) are soil proxi-indicators formed in situ as a result of the local interaction of soilformation factors over time. Since the soil memory is formed in situ, the soil record possesses a high spatial resolution at each point of the earth surface (Targulian and Goryachkin, 2004). As has been justly noted, during the investigation of the regular variation of soils in landscapes, two-dimensional transects are often accepted as a diagnostic tool, although the soil pattern must be regarded on a three or four dimensional basis (Sommer and Schlichting, 1997; Goryachkin, 2005). In our study, the mechanical migration of substance and aqueous migration of chemical elements as a result of the erosion of a slope catena are paragenetically linked with the processes within the area of the trans-accumulative catena (defensive ditch). While within the pedotopocatena on the slope of the defensive rampart the processes of soil-formation were taking place syngenetically with the surface washout of the soil within the limits of the thalweg of the ditch (with the growth of the length of the line of flow up to 270 and $431 \mathrm{~m}$ ), the pedogenesis was accompanied by processes of transportation of the sediments by water flow and their accumulation (Table 1).

A study of the interrelations between the structural and functional characteristics of geosystems and the migration of different chemical elements demonstrated (Semenova and Semenov, 2010) that the landscape diversity, along with factors such as the inclination and exposition of the slopes, the mineralogical, lithological and chemical composition of the rocks; and the species composition and layer-to-layer structure of plant associations, are defined inter alia by the specifics of the migration processes in the soils. In the course of movement of aqueous masses along the thalweg of the ditch, an increase in the transporting capacity of the water flow took place, as manifested in the geochemical features of the pedosediments. Within the transect-catena across the bottom of the ditch (from point 3 to point 5), using the average values of geochemical indices in the $0-30 \mathrm{~cm}$ layer of pedosediments, an importation of $\mathrm{Ca}$ and $\mathrm{Mg}$ contrary to stable elements ( $\mathrm{Ti}$, $\mathrm{Zr}, \mathrm{Al}$ ) and an increase in the contents of elements accumulated in the soil were found, indicating the actions elementary soil-formation processes (Table 4).

The values of the seven mobile chemical elements $(\mathrm{Sr}, \mathrm{V}, \mathrm{Cr}, \mathrm{P}, \mathrm{Cu}$, $\mathrm{Na}, \mathrm{Ca}$ ) due to aqueous migration (Perel'man, 1975) proved to be identical in structural agglomerations measuring $<1 \mathrm{~mm}$ in the upper layers of the soils of the trans-accumulative area of the ditch (point 3 and 4 ). In the pedosediments along the bottom of the ditch, the percentage of $\mathrm{SiO}_{2}$ decreased in relation to $\mathrm{Al}$ and $\mathrm{Fe}$ both due to more active importation of the minerals containing $\mathrm{Al}$ and $\mathrm{Fe}$ and because of the diminished influx of silica. Thus, owing to mesophytic vegetation covering the bottom of the ditch, the sediments arrived at the closing alignment of the defensive ditch (point 5) with a greater percentage of fine fractions. Therefore the percentage of the particles $<0.01 \mathrm{~mm}$ in the 10-centimetre layer of the soils was greater in points 4 and 5 at $1.74 \%$ and $2.65 \%$ respectively as compared with point 3 .

Soils within the limits of the thalweg (from point 3 to point 5 ) were characterized by a high content of humus but their differences were insignificant. However, along the flow line, the extent of humification of the organic substances (OM) and its mobility (the index Dm is one of the highest) was found to regularly decrease. Along the profile of pedosediments, the maximum mobility of OM (as may be judged from Dm) was found in the $50-70 \mathrm{~cm}$ layer, owing to a higher fraction HA-2 fraction and humine content and a lower HA-1 and HA-3 fractions (Table 3). In the $0-10 \mathrm{~cm}$ layer, the influence of importation of the soil material was found to be distinctly manifested. Notwithstanding the maximum OM content, this layer has the narrowest ratio Cha/Cfa (1.2), and a fairly high OM mobility with the maximal HA-1 content, a high content of Cfa (as in the lower strata of the profile). A qualitative leap was observable at the transition from 70 to $90 \mathrm{~cm}$ to $90-95 \mathrm{~cm}$. This was due to fulvatization of the humus with a lower content of $\mathrm{C} \mathrm{hu}$ mines and a higher HA-3 fraction, one of the lowest Dm values, which nowhere else was found in the profile of the pedosediments, and a medium enrichment of the humus with nitrogen. In the lowest stratum of the profile, the content of Cfa and the percentage of the HA-3 fraction were at their maximal values. 


\subsection{Pedosediments in the closing alignment of the defensive ditch}

As demonstrated earlier (Pla-Pueyo et al., 2015), through sedimentological studies, it is possible to determine the cyclicity defined by the climate and the time intervals during which certain sediments dominated. Over the last 40 years, the rapid accumulation of pedosediments on the bottoms of ravines in the Central Chernozem area (Sycheva et al., 2003) has been determined not only by intensive agriculture at the catchment areas but also by the stirring up of erosion processes due to the increase in the sum of precipitation during this period.

The stability of topsoil aggregates is a valuable indicator of the runoff and inter-rill erosion (Cantón et al., 2009). It has been established (Tanasienko et al., 2011) that the granulometric composition of products of a solid flow is certainly finer than that of the initial soil. The weight growth occurs owing to a decrease in the content of coarse dust $(0.05-0.01 \mathrm{~mm})$ in it and an increase in the quantity of the clay fraction $(<0.001 \mathrm{~mm})$.

The water erosion process results in selective importation of particles with a lesser solid phase density that are enriched in organic substances. As has been experimentally established (Khan et al., 2007), among these particles, those with a hydraulic size $<0.01 \mathrm{~mm}$ are most actively involved in the transportation of the alluvia.

The lowest layer of the pedosediments $(95-100 \mathrm{~cm})$ accumulated the alluvia during the period of fortification installation when there was still no vegetation with any considerable soil-protective capacity (Table 2). It is exactly for this reason that in this layer the highest content of particles $<0.01 \mathrm{~mm}$ was found among all the studied soils ( $>70 \%$ ) with simultaneous absence of colloids. The main regularity of the profile distribution of granulometric fractions throughout the thickness of pedosediments showed a stable increase in the sum of fractions $<0.01 \mathrm{~mm}$ below the depth of $50 \mathrm{~cm}$. In the closing alignment, the $30-50 \mathrm{~cm}$ layer, in terms of its physical properties, also provides a distinct boundary marking the change in the type of surface water runoff. Indeed, while the presence of particles measuring $0.05-0.25 \mathrm{~mm}$ (fraction of fine sand) was recorded in this layer, any material of this size was absent lower along the profile. Moreover, the highest content of particles $>0.01 \mathrm{~mm}$, including coarse dust, was observed here, but the presence of colloids was also notable $(<0.0001 \mathrm{~mm})$. The main boundary in the stratigraphy of pedosediments is shown in Fig. $2\left(\mathrm{t}_{2}\right)$ over the $\mathrm{D}$ (threshold distance) value along Y-axis. The raised content of particles measuring $<0.001 \mathrm{~mm}$ was found in the $50-95 \mathrm{~cm}$ layer, including the zone of $70-90 \mathrm{~cm}$ where the

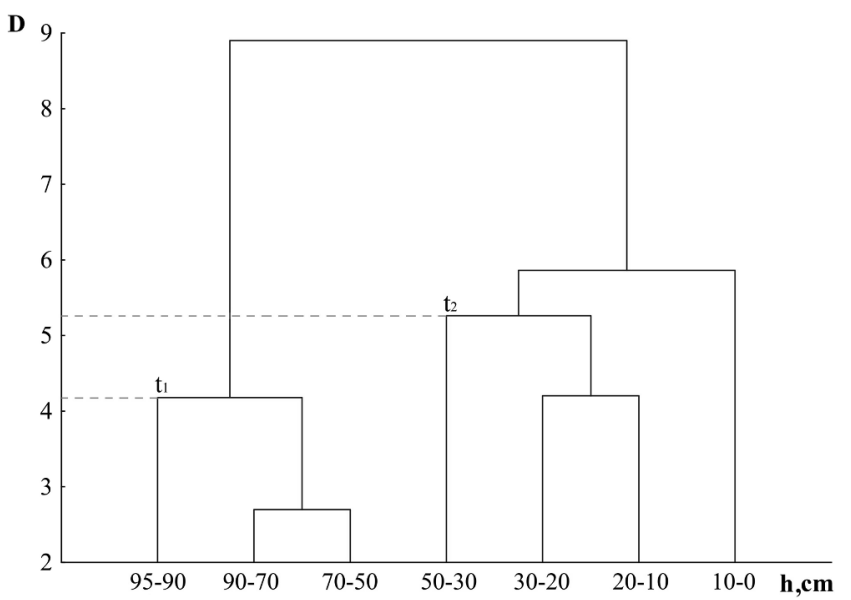

Fig. 2. Dendrogram of grouping of layers of pedosediments in the closing alignment of the defensive ditch: $\mathrm{D}$ - threshold distance. $\mathrm{t}_{1}$ - initial stage of the accumulation of sediments (first 20 years); $t_{2}$ - the boundary marking the change of the type of the surface runoff of water (turn between the second and third decade of the 19th century). sum of particles $<0.0005 \mathrm{~mm}$ (clay and colloids) was greater than in the higher and lower layers of the profile of the pedosediments. Chronologically, the 70-90 cm layer corresponds to the initial period of sedimentation (1666-1741) when the surface of the earthen defences was poorly protected by vegetation and the influence of water flow was most effective. It is noteworthy that in particles $<1 \mathrm{~mm}$, the maximum sum of the seven mobile chemical elements through water migration (Sr, V, Cr, P, Cu, Na, Ca) (Perel'man, 1975) was found in the $90-95 \mathrm{~cm}$ layer, while $70-90$ and $95-100 \mathrm{~cm}$ layers were slightly inferior to it.

There is a need for studies on geochemical changes occurring in specific grain-size fractions over the course of pedogenesis and lateral translocation of soil material (Samonova and Aseeva, 2009, Samonova et al., 2018). The relative scarcity of chemical elements in particles $<1 \mathrm{~mm}$ in comparison with the soil in general or the absence of differences have been noted for the landscape-geochemical systems and the depths of the profiles (soils and sediments) where the selective effects of the water-erosion processes were recorded. On the contrary, intra-profile zones (in soils at depths of over $20 \mathrm{~cm}$ and in deluvium at the depths of $20-30$ and $50-70 \mathrm{~cm}$ ) were found to be characterized by the highest extent of chemical element (especially $\mathrm{Pb}, \mathrm{V}$ ) enrichment in particles $<1 \mathrm{~mm}$.

After the construction of the defences ( $367 \mathrm{BP}$ ), Na, Mg, As, Al began to be accumulated in the sediments of the closing alignment of the ditch in concentrations selectively enriched by the water flow. The same tendency for As and Na continued even later as indicated by the contents of these elements in the covering layers of pedosediments.

Analysis of the layer-by-layer content of chemical elements in the pedosediments of the closing alignment of the ditch demonstrated the greatest enrichment in particles $<1 \mathrm{~mm}$ relative to the entire soil for $\mathrm{Cr}$, Ca, P and in lesser degree for Sr, As, Ba, Ni. Cobalt is the only element for which no such enrichment was found. It is noteworthy that in the profile of forest-steppe Chernozems (Protasova and Shcherbakov, 2003), the coefficients of correlation between the contents of cobalt and granulometric fractions from 0.01 to $1 \mathrm{~mm}$ were negative, while for fractions $<0.01 \mathrm{~mm}$, they were positive $(\mathrm{r}=0.57)$.

Along the profile of the pedosediments, the maximum OM mobility (Dm) was recorded in the $50-70 \mathrm{~cm}$ layer and was induced by a higher HA-2 fraction and humines content and a smaller HA-1 and HA-3 fractions (Table 3). The influence of the importation of soil material was distinctly traceable in the $0-10 \mathrm{~cm}$ layer. With the maximum $\mathrm{OM}$ content and HA-1 fraction in this layer, there is the narrowest Cha/Cfa ratio (1.2), a high OM mobility, and a considerable (like in the lowest layers of the profile) content of Cfa. A qualitative leap is notable at the transition from 70 to $90 \mathrm{~cm}$ to $90-95 \mathrm{~cm}$, which is manifested, for example, by fulvatization of the humus, an increase in the HA-3 fraction, and one of the lowest Dm values. The average enrichment of the humus in nitrogen is encountered nowhere else within the profile of the pedosediments. The very lowest layer of pedosediments is peculiar in terms of having the maximum Cfa content and the highest HA-3 fraction percentage.

The geochemistry of sediments has now moved from studies of particular chemical elements to investigations of their paragenetic associations (Semenkov et al., 2013; Samonova et al., 2018), which can reflect the processes of migration, accumulation, etc. The classification of elements by Perel'man (1975) has enabled the definition of the paragenetic association of elements, which migrate in combination and are concentrated at geochemical barriers. Over the profile of pedosediments $(0-95 \mathrm{~cm})$ the sum of the mobile $(\mathrm{Ca}, \mathrm{Na}, \mathrm{Mg}, \mathrm{Sr})$ and weakly mobile $(\mathrm{K}, \mathrm{Ba}, \mathrm{Rb})$ elements grows with the depth in the layer of $0-30 \mathrm{~cm}$ but at the depth of $70-95 \mathrm{~cm}$ it has its minimum values. It is natural that the utmost values of the Ke coefficient, i.e. the intensification of the eluvial process, are recorded beginning at a depth of $70 \mathrm{~cm}$. The metre-high profile of the pedosediments, during a combined analysis of a series of geochemical features is subdivided into two qualitatively different strata; there are higher indices in the $0-50 \mathrm{~cm}$ 
Table 5

The most informative indicators of physicochemical properties of soils and sediments.

\begin{tabular}{|c|c|c|c|c|c|c|c|c|c|c|c|}
\hline \multirow[t]{2}{*}{ Point no. } & \multirow[t]{2}{*}{ Layer, cm } & \multicolumn{2}{|c|}{ Content of particles (\%) with the size, $\mathrm{mm}$} & \multirow[t]{2}{*}{$\mathrm{pH}_{\mathrm{H} 2 \mathrm{O}}$} & \multirow[t]{2}{*}{$\mathrm{CO}_{2}, \%$} & \multirow[t]{2}{*}{ Si:Al } & \multirow[t]{2}{*}{$(\mathrm{CaO}+\mathrm{MgO}): \mathrm{Al}_{2} \mathrm{O}_{3}$} & \multirow[t]{2}{*}{$\mathrm{S}_{\mathrm{A},} \mathrm{ppm}$} & \multirow[t]{2}{*}{$\mathrm{Ke}$} & \multirow[t]{2}{*}{$\mathrm{CaO}: \mathrm{TiO}_{2}$} & \multirow[t]{2}{*}{$\Sigma \mathrm{mob}, \mathrm{ppm}$} \\
\hline & & $>0.01$ & $<0.005$ & & & & & & & & \\
\hline \multicolumn{12}{|c|}{ Catena on the slope of the rampart } \\
\hline \multirow[t]{3}{*}{1} & $0-14$ & 33.67 & 30.09 & 8.12 & 0.97 & 5.20 & 0.21 & 45 & 13.51 & 2.05 & 567 \\
\hline & $14-20$ & 31.28 & 33.85 & 8.23 & 1.62 & 5.37 & 0.27 & 44 & 12.35 & 2.98 & 596 \\
\hline & $20-30$ & 32.21 & 33.86 & 8.45 & 3.02 & 6.05 & 0.49 & 34 & 9.19 & 6.09 & 573 \\
\hline \multirow[t]{3}{*}{2} & $0-10$ & 30.61 & 35.18 & 7.91 & 1.19 & 5.67 & 0.21 & 42 & 14.72 & 1.95 & 596 \\
\hline & $10-20$ & 33.80 & 30.73 & 7.52 & 1.15 & 5.15 & 0.21 & 43 & 13.53 & 2.09 & 598 \\
\hline & $20-30$ & 36.36 & 28.43 & 7.56 & 1.29 & 5.69 & 0.25 & 43 & 12.67 & 2.41 & 586 \\
\hline \multirow[t]{3}{*}{3} & $0-10$ & 34.25 & 29.40 & 6.95 & 1.08 & 5.83 & 0.20 & 40 & 14.30 & 1.78 & 624 \\
\hline & $10-20$ & 35.27 & 28.01 & 7.23 & 0.97 & 5.56 & 0.19 & 42 & 14.58 & 1.71 & 564 \\
\hline & $20-30$ & 33.93 & 30.23 & 6.34 & 0.86 & 5.54 & 0.18 & 43 & 15.41 & 1.77 & 568 \\
\hline \multicolumn{12}{|c|}{ Transect-catena in the bottom of the ditch } \\
\hline \multirow[t]{3}{*}{4} & $0-10$ & 32.51 & 31.56 & 6.95 & 1.08 & 4.99 & 0.22 & 50 & 12.42 & 2.12 & 592 \\
\hline & $10-20$ & 32.13 & 32.52 & 6.98 & 0.97 & 5.01 & 0.19 & 46 & 13.58 & 1.89 & 609 \\
\hline & $20-30$ & 31.95 & 32.25 & 7.29 & 0.97 & 5.11 & 0.20 & 49 & 13.77 & 1.91 & 591 \\
\hline \multirow[t]{8}{*}{5} & $0-10$ & 31.48 & 33.07 & 7.37 & 1.35 & 5.26 & 0.22 & 50 & 13.20 & 2.14 & 562 \\
\hline & $10-20$ & 30.58 & 33.89 & 7.00 & 1.19 & 5.06 & 0.21 & 47 & 13.37 & 1.94 & 589 \\
\hline & $20-30$ & 31.21 & 33.47 & 7.70 & 1.40 & 5.16 & 0.24 & 49 & 11.83 & 2.36 & 597 \\
\hline & $30-50$ & 32.37 & 32.14 & 7.90 & 1.29 & 4.90 & 0.21 & 50 & 13.13 & 2.33 & 576 \\
\hline & $50-70$ & 30.17 & 34.58 & 7.65 & 1.08 & 4.87 & 0.19 & 51 & 14.14 & 1.86 & 560 \\
\hline & $70-90$ & 30.45 & 35.46 & 7.56 & 0.97 & 4.72 & 0.18 & 50 & 14.08 & 1.76 & 560 \\
\hline & 90-95 & 30.38 & 35.51 & 7.68 & 1.08 & 4.87 & 0.18 & 50 & 13.79 & 1.65 & 561 \\
\hline & 95-100 & 29.84 & 36.11 & 7.87 & 0.97 & 4.89 & 0.20 & 49 & 13.91 & 1.77 & 570 \\
\hline
\end{tabular}

Note: $\mathrm{S}_{\mathrm{A}}$ is the sum of the elements accumulated in the soil (P, Ca, K, Mg, Mn, Cu) (Perel'man, 1975).

layer as compared with the lower one: $\mathrm{CaO} / \mathrm{TiO}_{2}, \mathrm{CaO} / \mathrm{ZrO}_{2}, \mathrm{SiO}_{2}$ / $\mathrm{Al}_{2} \mathrm{O}_{3}$, sum of the mobile and weakly mobile elements, but lower values of $(\mathrm{CaO}+\mathrm{MgO}) / \mathrm{Al}_{2} \mathrm{O}_{3}$ and $\mathrm{Ke}$ (Table 5). Simultaneously, in the $0-50 \mathrm{~cm}$ layer, the extent of eluviation is lower than that in the deeper layers, while the contents of mobile and weakly mobile elements are lower $-8 \%$ and $3 \%$ respectively.

\subsection{Rhythm of denudation processes}

Where it is possible in the understanding of spacial-temporal regularities to move from qualitative notions to quantitative evaluations, the key tasks include the recording (dating) of the initial moment of the origination of processes and the revealing of their chrono-organization defined by the influence of the external environment. The exploration of ramparts and walls from different periods (Baitinger and Kresten, 2012; Grützner et al., 2012; Nadel et al., 2013; Šekularac et al., 2017) gives us the possibility of understanding the evolution of the soil-geomorphologic interrelations in dated pedotopocatenas.

The fortifications investigated here as on-location models of natural processes, are unique in the fact that the beginning of their functioning is dated reliably and precisely, rather than over 367 years BP. The pedosediments in the closing alignment of the defensive ditch (near its transition into the upper reaches of the arisen ravine) are an important source of information on the integral result of the emergence of erosionaccumulative processes. The transition from the lower boundary of the pedosediments to the original bottom of the defensive ditch was reliably recorded in the soil section, e.g., iron-containing sandstone, which undoubtedly appeared in the initial period of its construction and was found in situ at a depth of $100 \mathrm{~cm}$. Of note is the practice of paving the bottom of a ditch with small size rubble, which was revealed during investigations of fortification constructions from the first century $\mathrm{AD}$ in the region of Olbia (Bujskikh, 1991, p. 91).

Previous analysis of the physicochemical and geochemical properties of pedosediments identified the 14 most informative indicators: CaO:TiO ${ }_{2} ; \mathrm{Si}: \mathrm{Al} ;(\mathrm{CaO}+\mathrm{MgO}): \mathrm{Al}_{2} \mathrm{O}_{3} ; \mathrm{S}_{\mathrm{A}} ; \mathrm{Ke}$; fraction of particles 0.001-0.005 mm and > 0.01 mm; Corg; Cha/Cfa; C/N; Dm; HA-1, percent of the amount of HA; HA-3, percent of the amount of HA; Cfa, percent of Corg. The determined system of 14 pedogenic indicators was used for the classification and chronostratigraphy of pedosediments, which was identified through iterative calculations of the rates of accumulation. The grouping of strata of the pedosediments was realized using their normalized values by the method of hierarchic classification (Fig. 2). However, in relation to the stratigraphic division of the pedosediment thickness, it was shown that the circle of indicators has become narrower. Assuming conditionally that climate variations and, in particular, precipitation, over 3.5 centuries were at the level of fluctuations, the particle size distribution and chemical properties of the individual layers in the pedosediment thickness should be similar. However, earlier obtained palaeoclimatic reconstructions (Borisenkov and Kobysheva, 1981, Barash, 1989, Zolotokrylin et al., 1992) do not indicate the climatic uniformity of such a long period. Our search for the qualitatively different layers of pedosediments consisted of the selection of those physicochemical and geochemical parameters (Tables 2 and 3) according to the accepted criterion. This criterion was the variability of an indicator at a level above the average, when the coefficient of variation $(\mathrm{V})$ was $\mathrm{V} \geq 10 \%$. As a result, the most informative soil indicators were identified as markers of erosion activity variability (Table 5).

Morphologically, the thickness of pedosediments was found to be $950 \mathrm{~mm}$. This value, considering the term recorded as the end of the construction of the fortifications, allowed us to estimate the average annual rate of accumulation of the sediments as $2.58 \mathrm{~mm} \mathrm{yr}^{-1}$. Considering this rate, the time span of the formation of the upper $50 \mathrm{~cm}$ of the pedosediments can be roughly dated to that period of 1818-2013. Through the value of the threshold distance, Fig. 2 indicates the genetic boundary in the properties of the pedosediments to be higher and lower than $50 \mathrm{~cm}$, i.e., the $1820 \mathrm{~s}$. The layer at the depth of $50 \mathrm{~cm}$ can be related to the most essential qualitative transition during that period from the mid-18th to the early 19th century (1741-1821). This was a more humid period than the subsequent one. This boundary is shown as $t_{2}$ in Fig. 2. The main difference in the layers over the thickness of 50 to $90 \mathrm{~cm}$ covering the period of 155 years (1666-1821) from later pedosediments is in the fact that the former strata were formed under conditions of a dryer climate with rather small rates of erosion.

A previously obtained dependence between the increase in rubidium content relative to its background content in humic soil horizons and the average annual atmospheric precipitations reconstructed 

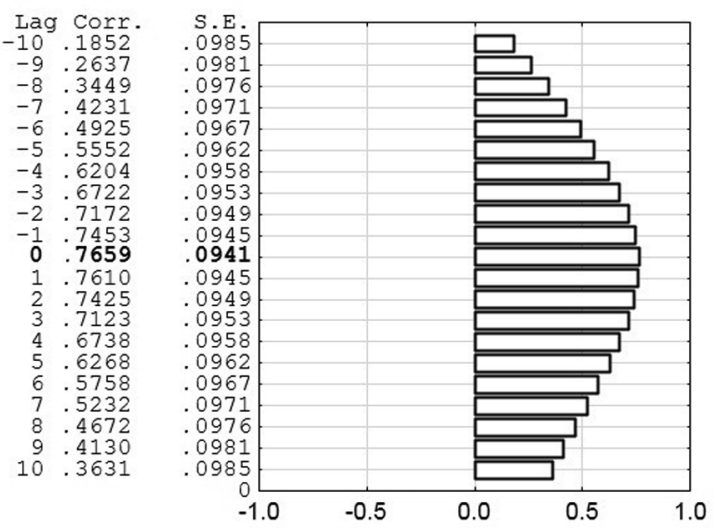

a)

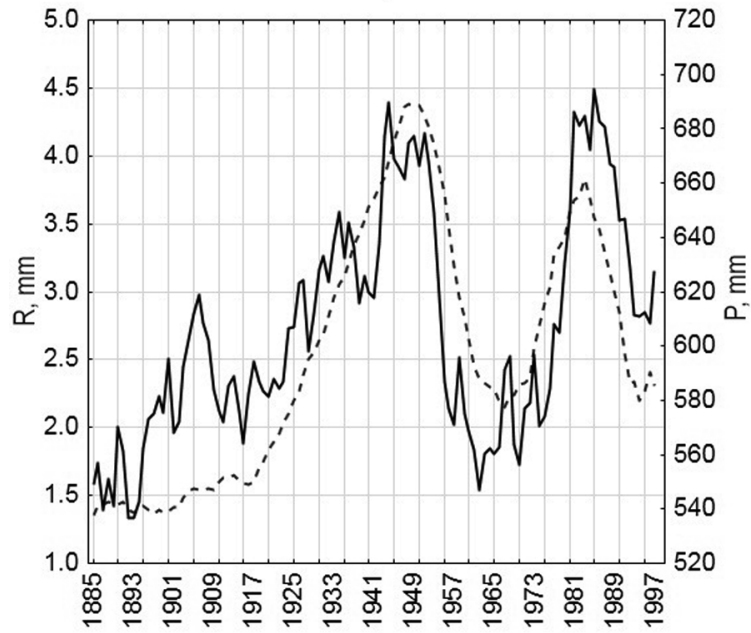

c)

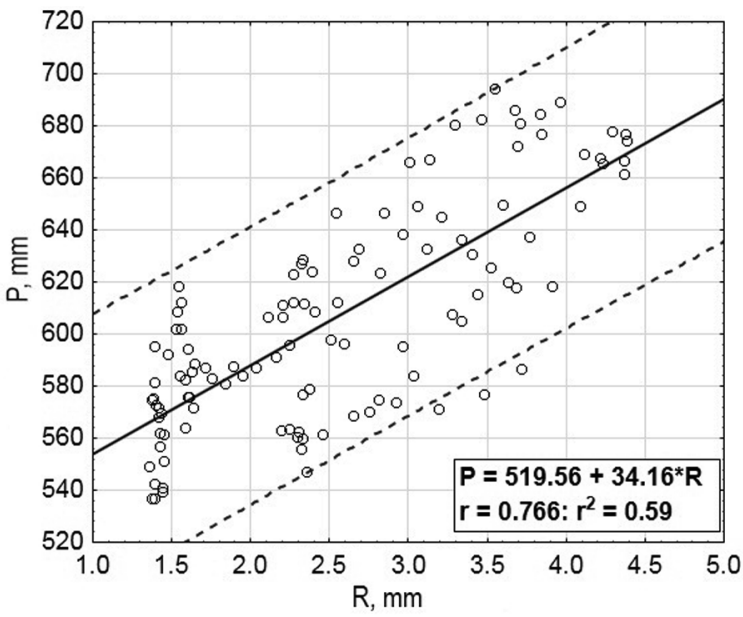

b)

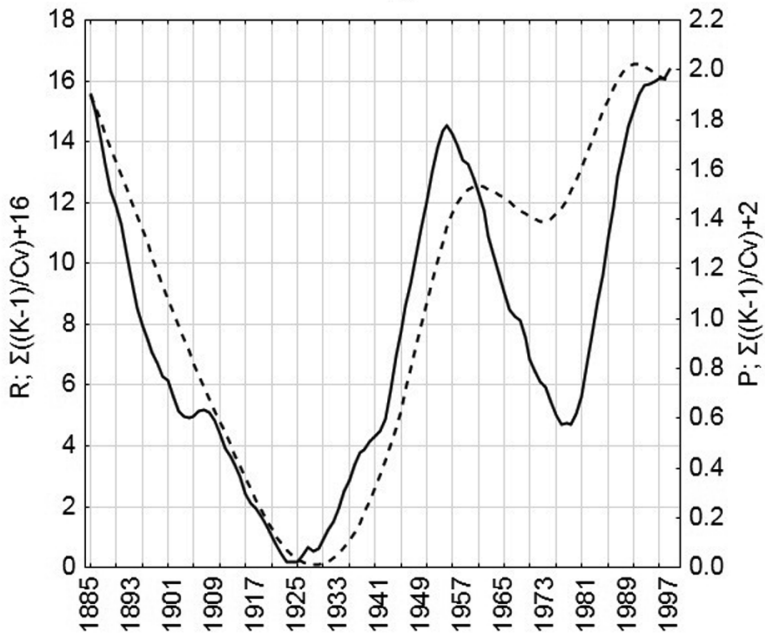

d)

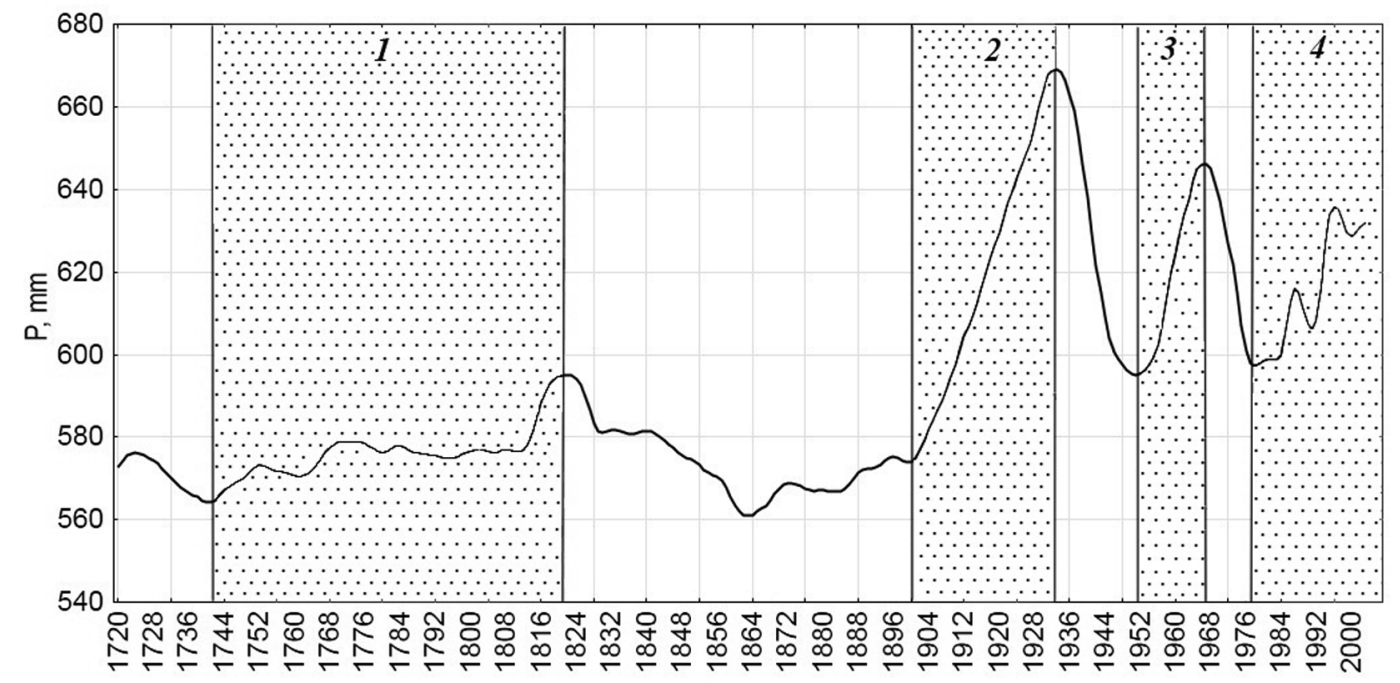

e)

Fig. 3. Reconstruction of the rhythms of precipitation for many years on the basis of dendrochronological data: (a) cross-correlation; (b) function of the correlation; (c) moving smooth with 11-year period; (d) integral curves; (e) rhythms of the summary annual precipitations (series reconstructed through radial growth of an oak): 1 - period of 1741-1821, 2 - period of 1890-1935; 3 - period of 1952-1966; 4 - period of 1976-2013. 
through magnetic data (Kalinin and Alekseev, 2011) suggests that, in the thickness of pedosediments, a more humid situation is diagnosed by a higher content of $\mathrm{Rb}$ (from 79.9 to $81.4 \mathrm{ppm}$ ) in 0-30 cm layer, while 70-90 and 50-70 cm layers correspond through the lowest concentration of $\mathrm{Rb}(77.6$ and $77.8 \mathrm{ppm})$ to more xerothermic periods.

Since at the depths of $0-10,20-30$ and $50-70 \mathrm{~cm}$ in the pedosediments of the closing alignment of the ditch, the frequency of the values of the coefficient of enrichment of particles $<1 \mathrm{~mm}$ relative to the soil $(>1 \mathrm{~mm}$ ) is the greatest, the respective chronological periods (approximately 1976-2013, 1890-1935 and 1741-1821) can be considered to have been the most humid ones over the last 3.5 centuries. This fact has been confirmed by historic climatic reconstructions: from the $1560 \mathrm{~s}$, a new cold period began and continued into the 17th century (Barash, 1989). In the southern part of the East European plain during the minor glacial period, the series of humid years increased, especially in the time span of 1650-1750 (Zolotokrylin et al., 1992). Dendrochronological data show (Solomina et al., 2011) that the 17th century was the one with the most contrasting conditions (15 positive and negative anomalies in annual radial growth). In the 18th century, in the European part of Russia, the climatic conditions were characterized by a considerable number of long rainy periods and numerous inundations, and a cooling of the climate was recorded at the beginning of the 19th century (Borisenkov and Kobysheva, 1981).

Since the instrumental registration of the annual precipitation at the basic weather bureau began in 1885 , we calculated a retrospective series of annual sums of precipitations to as early as 1720 through cross-reconstruction using dendrochronological data (Fig. 3). A comparison of the periodicity of geomorphological and climatic events (Simonov, 1978) demonstrated that the cycles of the intensification of processes of erosion and accumulation correspond to a period of $\mathrm{k} \cdot 10^{0}$ (year) and are defined by a quasi-triennial climatic cycle.

The method of filtration (by means of a $4253 \mathrm{H}$ filter) yielded a smoothed series of annual sums of precipitations but simultaneously retained the main dynamic characteristics of the initial series (Fig. 3d). The reconstruction of the dynamics of the humid conditions allowed us to identify four qualitative periods representing in the changes in the annual sum of precipitation over 293 years when the intensity of the erosion was rising. This result is important for the interpretation of stratigraphic differences throughout the thickness of sediments. The reconstruction of the climate (Fig. 3e) has demonstrated that, in comparison with the norm of precipitations of many years $\bar{P}=550 \mathrm{~mm}$, in the first period of the rise of humidity there was an increase of the sum of precipitations at $4.8 \%\left(\Delta \bar{P}_{1}=+26.2 \mathrm{~mm}\right)$, in the second period - at $11.2 \%\left(\Delta \bar{P}_{2}=+61.7 \mathrm{~mm}\right)$, in the third period at $12.6 \%$ $\left(\Delta \bar{P}_{3}=+69.4 \mathrm{~mm}\right)$, and at the fourth - at $11.7 \%\left(\Delta \bar{P}_{4}=+64.4 \mathrm{~mm}\right)$.

\section{Conclusions}

As the analysis of physicochemical and geochemical differentiation throughout the profile of pedolitosediments accumulated over 3.5 centuries has demonstrated, characteristics such as the sum of the elements $(\mathrm{P}, \mathrm{Ca}, \mathrm{K}, \mathrm{Mg}, \mathrm{Mn}, \mathrm{Cu})$ accumulated in the soil, the percentage of particles $0.001-0.005 \mathrm{~mm}$ and $>0.01 \mathrm{~mm}$, the content of organic carbon and its qualitative composition, as well as the geochemical ratios and coefficients indicating the processes of leaching, can serve as palaeogeographic markers of climatic rhythm at the level of intra-secular changes under the conditions of forest-steppe.

The established rhythms of humidity allowed us to differentiate between the rates of sediment accumulation in the closing alignment of the defensive ditch throughout separate chronozones. A peculiar feature of the humidity of the soil from the $30-50 \mathrm{~cm}$ layer chronologically related to the 19th century is represented by the maximum intensification of the chernozem-formation process (an essential growth as compared with the higher and lower lying layers of the first and third fractions of HA against the respective lowering of the percentage of the close fractions of FA). This layer also differs in its granulometric composition, viz. it contains the maximum quantity of fine sand $(0.05-0.25 \mathrm{~mm})$ over the entire profile, more particles with a size of 0.01-0.05 mm, and, in general, more particles $>0.01 \mathrm{~mm}$, in comparison with the higher and lower strata. Most probably, this is explainable by a decrease in the projective vegetative cover in the thalweg due to its more xeromorphic character in the 19th century. The present-day soil typical of the forest-steppe climate in the $0-10 \mathrm{~cm}$ layer at $160 \mathrm{~m}$ higher along the thalweg (site 4-1) is characterised by the same features as the soil from the layer of $30-50 \mathrm{~cm}$. Since the pedogenic peculiarities of an erosion catena are distinctly recognizable through the presence of colloids and the sum of particles $<0.0005 \mathrm{~mm}$ (clay and colloids), it is possible to distinguish the positions in a landscape and chronozones in pedosediments where the transportation of alluvia dominated over pedogenesis: in point 4 of the entire profile and in the strata of $10-20 \mathrm{~cm}$ and over $70 \mathrm{~cm}$ in the closing alignment. The history of the formation of sediments over 3.5 centuries can be divided into the following stages: two pluvial periods of 1890-1935 and 1976-2013 corresponding to horizons of $30-20 \mathrm{~cm}$ and $10-0 \mathrm{~cm}$ in the closing alignment of the ditch, which were similar and amounted to 2.80 and $2.85 \mathrm{~mm} \mathrm{yr}^{-1}$ respectively. The longest periods of geomorphologic stability and xeromorphic character of the climatic conditions in 1821-1890 and 1666-1741 correspond to horizons of the sediments at the depth of $30-50 \mathrm{~cm}$ and $70-90 \mathrm{~cm}$ respectively with the average annual rates of the accumulation of the sediments of $2.47 \mathrm{~mm} \mathrm{yr}^{-1}$. An intermediate position is occupied by the period of 1741-1821 corresponding to the layer of $50-70 \mathrm{~cm}$ where the accumulation of sediments occurred with the average rate of $2.59 \mathrm{~mm} \mathrm{yr}^{-1}$. It is of note that the layer of $30-50 \mathrm{~cm}$ along with that of $10-20 \mathrm{~cm}$ have the lowest geometric values of the coefficient Kci calculated through the contents of 25 chemical elements in comparison to other strata in the ditch. This indicates a weak water flows energy and low erosion activity.

The results of this study confirm the effectiveness of a purposeful and wide (in the spatial and temporal terms) investigation of objects of anthropogenic relief formation which possess a drainage-geochemical series along the topographical gradient. These investigations aim to establish the soil-geomorphologic interrelations and calibration of mathematical models of natural processes based on on-location data. Through connection, the protection of historical and cultural heritage sites should become more complex, including the conduction of interdisciplinary natural and historical research.

\section{Appendix A. Supplementary data}

Supplementary data to this article can be found online at https:// doi.org/10.1016/j.catena.2019.104300.

\section{References}

Alekseev, A., Alekseeva, T., Kalinin, P., Hajnos, M., 2018. Soils response to the land use and soil climatic gradients at ecosystem scale: mineralogical and geochemical data. Soil Tillage Res. 180, 38-47. https://doi.org/10.1016/j.still.2018.02.008.

Amoakwah, E., Frimpong, K.A., 2013. Relationships between potassium forms and selected physico-chemical properties of some ghanaian soils along a toposequence. ARPN-JEAS 7, 525-533.

Atanassova, I., Teoharov, M., Ivanov, P., 2009. Characterisation of a fire affected catena sequence from Lyulin Mountain, Bulgaria. Bulgar. J. Agric. Sci. 4, 333340.

Avessalomova, I.A., 2009. Catenary geochemical differentiation of sub-mediterranean landscapes of the North-Western Caucasus. Vestnik Moskovskogo Universiteta, Seriya 5: Geografiya 2, 19-25.

Baitinger, H., Kresten, P., 2012. Geoarchaeology of two Hessian vitrified ramparts: Glauberg and Altkönig [Geoarchäologie zweier Hessischer 'schlackenwälle': Glauberg und Altkönig]. Archaologisches Korrespondenzblatt 4, 493-508.

Barash, S.I., 1989. Istoriya neurozhaev i pogody v Evrope (po XVI v.n.e) [History of Crop Failures and Weather in Europe (till 16th century AD)]. Gidrometeoizdat Publ. (In Russian), Leningrad.

Bartz, M., Rixhon, G., Kehl, M., El Ouahabi, M., Klasen, N., Brill, D., Weniger, G.-C., Mikdad, A., Brückner, H., 2017. Unravelling fluvial deposition and pedogenesis in ephemeral stream deposits in the vicinity of the prehistoric rock shelter of Ifri n'Ammar (NE Morocco) during the last 100 ka. Catena 152, 115-134. https://doi. org/10.1016/j.catena.2016.12.007.

Bevz, V.N., 2004. Some theoretical aspects of the study of slope landscapes. Vestn. VSU. Series: Geography. Geoecol. 1, 75-78 (In Russian). 
Bianchini, G., Cremonini, S., Di Giuseppe, D., Gabusi, R., Marchesini, M., Vianello, G., Vittori Antisari, L., 2019. Late Holocene palaeo-environmental reconstruction and human settlement in the Eastern Po Plain (northern Italy). Catena 176, 324-335. https://doi.org/10.1016/j.catena.2019.01.025.

Bockheim, J.G., Gennadiyev, A.N., Hammer, R.D., Tandarich, J.P., 2005. Historical development of key concepts in pedology. Geoderma 1-2, 23-36. https://doi.org/10 1016/j.geoderma.2004.03.004.

Borisenkov, E.P., Kobysheva, N.V., 1981. Study of climate and its applied aspects, in Proceedings of the technical conference on climate: Asia and western Pacific, held at Guangzhou, China, Dec 1980, (World Meteorological Organization, Geneva; WMO-578), pp. 267-273.

Bujskikh, S.B., 1991. The fortification of the Olbia State (the first centuries A.D.). Naukova Dumka, Kiev (In Russian).

Bulygin, S.Y., Lisetskiy, F.N., 1992. Soil microaggregation as an index of erosion resistance. Eurasian Soil Sci. 3, 59-65.

Campodonico, V.A., García, M.G., Pasquini, A.I., 2016. The geochemical signature of suspended sediments in the Parana River basin: Implications for provenance, weathering and sedimentary recycling. Catena 143, 201-214. https://doi.org/10. 1016/j.catena.2016.04.008.

Cantón, Y., Solé-Benet, A., Asensio, C., Chamizo, S., Puigdefábregas, J., 2009. Aggregate stability in range sandy loam soils Relationships with runoff and erosion. Catena 3, 192-199. https://doi.org/10.1016/j.catena.2008.12.011.

Chichagov, V.P., 2005. Man-induces disturbance in arid plains in the Late Holocene, Izvestiya Rossiiskoi akademii nauk. Seriya geograficheskaya 6, 26-37.

Cohen, S., Willgoose, G., Hancock, G., 2009. The mARM spatially distributed soil evolution model: a computationally efficient modeling framework and analysis of hillslope soil surface organization. J. Geophys. Res. Solid Earth 3, F03001. https://doi. org/10.1029/2008JF001214.

Copini, P., Decuyper, M., Sass-Klaassen, U., Gärtner, H., Mohren, F., den Ouden, J., 2015. Effects of experimental stem burial on radial growth and wood anatomy of pedunculate oak. Dendrochronologia 33, 54-60. https://doi.org/10.1016/j.dendro. 2014.12.001.

Deák, B., Valkó, O., Alexander, C., Mücke, W., Kania, A., Tamás, J., Heilmeier, H., 2014. Fine-scale vertical position as an indicator of vegetation in alkali grasslands - case study based on remotely sensed data. Flora 209, 693-697. https://doi.org/10.1016/j. flora.2014.09.005.

Deák, B., Tölgyesi, C., Kelemen, A., Bátori, Z., Gallé, R., Bragina, T.M., Yerkin, A.I., Valkó, O., 2017. The effects of micro-habitats and grazing intensity on the vegetation of burial mounds in the Kazakh steppes. Plant Ecol. Divers. 5-6, 509-520. https://doi. org/10.1080/17550874.2018.1430871.

Dergacheva, M.I., Ondar, E.E., Zakharova, E.G., 2010. Humus profiles of mountainchestnut soils of a complex catena in Central Tuva. Contemp Probl Ecol 3, 299-304. https://doi.org/10.1134/S1995425510030070.

Dixon, J.C., 2013. Pedogenesis with respect to geomorphology. Treatise Geomorphol. 4, 27-43. https://doi.org/10.1016/B978-0-12-374739-6.00058-0.

Dmitruk, Yu.M., Matviishina, Zh.M., Slyusarchuk, I.I., 2008. Soils of Trajan's Walls: evolutionary and ecologic-genetic analysis. Publisher: Ruta, Chernovtsy (In Ukrainian).

Dmytruk, Y., Matviyishyna, Z., Kushnir, A., 2014. Evolution of chernozem in the complex section at Storozheve, Ukraine. In: Soil as World Heritage. Springer, Dordrecht, pp. 91-100.

Dolgikh, A.V., 2011. Anthropogenic accumulation of chemical elements in urbosediments of the ancient cities of European Russia. Nauch. Ved. Belgorod. Gos. Univ Ser. Estestv. Nauki 15, 135-144.

Dyakonov, K.N., Bochkarev, Yu. N., Reteyum, A.Y., 2012. Geophysical and astrophysical factors governing biological productivity of landscapes at the northern and the upper forest lines. Vestnik Moskovskogo Universiteta, Seriya 5: Geografiya 4, 3-8.

FAO World reference base for soil resources. 1998. ISSS-ISRIC-FAO. World soil resources report No. 84. Rome, Italy, pp. 187.

Fitze, P., Egli, M., 2000. Formulation of pedologic mass balance based on immobile elements: a revision. Soil Sci. 5, 437-443. https://doi.org/10.1097/00010694200005000-00008.

Florinsky, I.V., Eilers, R.G., Manning, G.R., Fuller, L.G., 2002. Prediction of soil properties by digital terrain modelling. Environ. Modell. Softw. 3, 295-311. https://doi.org/10. 1016/S1364-8152(01)00067-6.

Fridland, V.M., 1974. Structure of the soil mantle. Geoderma 1-2, 35-41. https://doi.org/ 10.1016/0016-7061(74)90036-6.

Gabriela, A.I.R., Da Costa, L.M., Carlos, E.G.R.S., Filho, E.I.F., Gaggero, M.R., De Souza, E., 2005. Digital terrain analysis: Tool for pedoform identification in the "mar de morros' watershed (MG) [Análise digital do terreno: Ferramenta na identificação de pedoformas em microbacia na região de 'mar de morros' (MG)]. Revista Brasileira de Ciencia do Solo 2, 269-276.

Garnier, J., Quantin, C., Guimarães, E., Garg, V.K., Martins, E.S., Becquer, T., 2009. Understanding the genesis of ultramafic soils and catena dynamics in Niquelândia, Brazil. Geoderma 3-4, 204-214. https://doi.org/10.1016/j.geoderma.2009.04.020.

Gennadiev, A.N., 1984. Temporal variability of chernozem properties and the evolution of natural environment. Vestn. Mosk. Univ Ser. Geogr. 5, 10-16.

Gennadiev, A.N., Kasimov, N.S., 2004. Lateral migration of substances in soils and soilgeochemical catenas. Eurasian Soil Sci. 12, 1286-1300.

Gennadiev, A.N., Koshovskii, T.S., Zhidkin, A.P., Kovach, R.G., 2013. Lateral migration of soil solid-phase material within a landscape-geochemical arena detected using the magnetic tracer method. Eurasian Soil Sci. 10, 983-993. https://doi.org/10.1134/ S1064229313100037.

Gennadiev, A.N., Smirnova, M.A., 2012. Soil catenas at the slopes of sinkholes. Vestnik Moskovskogo Universiteta. Seriya 5: Geografiya 3, 74-79.

Gerrard, A.J., 1981. Soils and landforms: an integration of geomorphology and pedology. George Allen and Unwin, Boston, MA, London.

Glazovskaja, M.A., 1999. Geohimija prirodnyh i tehnogennyh landshaftov [Geochemistry of natural and anthropogenic landscapes]. Vysshaja Shkola, Moscow (In Russian).

Goleusov, P.V., Lisetskii, F.N., 2008. Soil development in anthropogenically disturbed forest-steppe landscapes. Eurasian Soil Sci. 13, 1480-1486. https://doi.org/10.1134/ S1064229308130188.

Golosov, V.N., Ivanova, N.N., Gusarov, A.V., Sharifullin, A.G., 2017. Assessment of the trend of degradation of arable soils on the basis of data on the rate of stratozem development obtained with the use of ${ }^{137} \mathrm{Cs}$ as a chronomarker. Eurasian Soil Sci. 10 1195-1208. https://doi.org/10.1134/S1064229317100039.

González-Arqueros, M.L., Vázquez-Selem, L., Gama Castro, J.E., McClung de Tapia, E. 2017. Late Holocene erosion events in the Valley of Teotihuacan, central Mexico: insights from a soil-geomorphic analysis of catenas. Catena 158, 69-81.

Goryachkin, S.V., 2005. Studies of the soil cover patterns in modern soil science: ap proaches and tendencies. Eurasian Soil Sci. 12, 1301-1308.

Grützner, C., Bemmann, J., Berking, J., Frechen, M., Klinger, R., Klitzsch, N., Linzen, S., Mackens, S., Oczipka, M., Piezonka, H., Reichert, S., Schneider, M., Schütt, B., 2012. Improving archaeological site analysis: a rampart in the middle Orkhon Valley investigated with combined geoscience techniques. J. Geophys. Eng. 4, S70-S80. https://doi.org/10.1088/1742-2132/9/4/S70.

Han, Y.-S., Youm, S.-J., Oh, C., Cho, Y.-C., Ahn, J.S., 2017. Geochemical and eco-toxicological characteristics of stream water and its sediments affected by acid mine drainage. Catena 148, 52-59. https://doi.org/10.1016/j.catena.2015.11.015.

Henkner, J., Ahlrichs, J.J., Downey, S., Fuchs, M., James, B.R., Knopf, T., Scholten, T. Teuber, S., Kühn, P., 2017. Archaeopedology and chronostratigraphy of colluvial deposits as a proxy for regional land use history (Baar, southwest Germany). Catena 155, 93-113. https://doi.org/10.1016/j.catena.2017.03.005.

Hubert-Ferrari, A., El-Ouahabi, M., Garcia-Moreno, D., Avşar, U., Altınok, S., Schmidt, S., Fagel, N., Çağatay, M.N., 2017. Earthquake imprints on a lacustrine deltaic system: the Kürk Delta along the East Anatolian Fault (Turkey). Sedimentology 5 , 1322-1353. https://doi.org/10.1111/sed.12355.

Hwang, T., Band, L., Hales, T.C., 2009. Ecosystem processes at the watershed scale: extending optimality theory from plot to catchment. Water Resour. Res. 11, W11425. https://doi.org/10.1029/2009WR007775.

Istoricheskaya letopis Kurskogo dvoryanstva [Historical chronicle of the Kursk nobility]. 1913. V. 1. Moscow (In Russian).

Jacobs, P.M., Konen, M.E., Curry, B.B., 2009. Pedogenesis of a catena of the FarmdaleSangamon Geosol complex in the north central United States. Palaeogeography, Palaeoclimatol., Palaeoecol. 1-4, 119-132. https://doi.org/10.1016/j.palaeo.2009. 08.017.

Kachinsky, V.L., Gennadiev, A.N., 2010. Soil catenas in the basins of Bureya and Selemdzha rivers (the Amur River region). Vestnik Moskovskogo Universiteta. Seriya 5: Geografiya 4, 34-39.

Kalinin, P.I., Alekseev, A.O., 2011. Geochemical characterization of loess-soil complexes on the Terek-Kuma Plain and the Azov-Kuban' Lowland. Eurasian Soil Sci. 12, 1315-1332. https://doi.org/10.1134/S1064229311120039.

Kasimov, N.S., Gennadiev, A.N., 2008. Landscape-geochemical and soil-geographical school. Basic scientific concepts, in: Geographical scientific schools of Moscow University. Gorodets, Moscow, pp. 198-228.

Kenderessy, P., Lieskovský, J., 2014. Impact of the soil erosion on soil properties along a slope catena - case study Horný Ohaj Vineyards, Slovakia. Carpath J. Earth Env. 2, 143-152.

Khan, K.Yu., Pozdnyakov, A.I., Son, B.K., 2007. Structure and stability of soil aggregates. Eurasian Soil Sci. 4, 409-414. https://doi.org/10.1134/S1064229307040060.

Kononova, M.M., Alexandrova, I.V., 1973. Formation of humic acids during plant residue humification and their nature. Geoderma 3, 157-164. https://doi.org/10.1016/ 0016-7061(73)90056-6.

Kozlenko, R.A., 2015. Roman fort on the border of the Olbian state, in: LAUREA I. Antique world and the Middle Ages. Kharkov, pp. 28-33.

Labaz, B., Musztyfaga, E., Waroszewski, J., Bogacz, A., Jezierski, P., Kabala, C., 2018. Landscape-related transformation and differentiation of Chernozems - Catenary approach in the Silesian Lowland, SW Poland. Catena 161, 63-76. https://doi.org/10. 1016/j.catena.2017.10.003.

Linstädter, J., Kehl, M., Broich, M., López-Sáez, J.A., 2016. Chronostratigraphy, site formation processes and pollen record of Ifri n'Etsedda, NE Morocco. Quat. Int. 410, 6-29. https://doi.org/10.1016/j.quaint.2015.11.017.

Lisetskii, F.N., 1999. Soil catenas in archeological landscapes. Eurasian Soil Sci. 10, 1084-1093.

Lisetskii, F.N., Goleusov, P.V., Chepelev, O.A., 2013. The development of chernozems on the dniester-prut interfluve in the Holocene. Eurasian Soil Sci. 5, 491-504. https:// doi.org/10.1134/S1064229313050086.

Lisetskii, F.N., Sudnik-Wojcikowska, B., Moysiyenko, I.I., 2016. Flora differentiation among local ecotopes in the transzonal study of forest-steppe and steppe mounds. Biol Bull 2, 169-176. https://doi.org/10.1134/S1062359016010106.

Lisetskii, F.N., Mitryaykina, A.M., Slivchenko, E.N., 2007. Time series of values of the radial growth of trees of a typical forest-steppe. Certificate of official registration of the database №2007620209. Registred in the Register of databases 13.06.2007.

Lisetskii, F.N., Svetlitchnyi, A.A., Chornyy, S.G., 2012. Recent developments in erosion science. A. A. Svetlitchnyi (Ed.). Belgorod. ISBN 978-5-9786-0248-7. https://doi.org/ 10.13140/2.1.1029.9682 (In Russian).

Lisetsky, F.N., Polovinko, V.V., 2012. Erosion catena's on earthen fortifications. Geomorfologiya 2, 65-78. https://doi.org/10.15356/0435-4281-2012-2-65-77.

Liu, G., Li, L., Wu, L., Wang, G., Zhou, Z., Du, S., 2009. Determination of soil loss tolerance of an entisol in Southwest China. Soil Sci. Soc. Am. J. 2, 412-417. https://doi. org/10.2136/sssaj2008.0155.

Malinowska, E., Ceglińska, K., 2011. Spatial variability of soil properties in the slope catenas in the vicinity of Murzynowo (central Poland) | [Przestrzenna zmienność właściwości gleb w układach katenalnych w rejonie murzynowa]. Prace i Studia Geograficzne 46, 77-92.

Maslennikov, A.A., 2003. Ancient earth frontier and structures in the East Crimea. Griff and K, Tula. (In Russian).

Milne, G., 1935. Some suggested units of classification and mapping, particularly for East African soils. Soil Res. 3, 183-189.

Morgan, R.P.C., 1979. Soil Erosion. Longman, London and New York, pp. 113. 
Munsell Color. Munsell soil color charts: year 2000. 2000. Revised Washable Edition. GretagMacbeth Grand Rapids, MI., New Windsor.

Murphy, P.N.C., Ogilvie, J., Meng, F.-R., White, B., Bhatti, J.S., Arp, P.A., 2011. Modelling and mapping topographic variations in forest soils at high resolution: a case study. Ecol. Model. 14, 2314-2332. https://doi.org/10.1016/j.ecolmodel.2011.01.003.

Nadel, D., Bar-Oz, G., Avner, U., Malkinson, D., Boaretto, E., 2013. Ramparts and walls: building techniques of kites in the Negev Highland. Quat. Int. 297, 147-154. https:// doi.org/10.1016/j.quaint.2012.11.037.

Nour, D.D. (Ed.), 2001. Soil erosion, the essence of the process, consequences, minimization, stabilization. Pontos, Chişinău. 428 p. (In Russian).

Ollier, C.D., 1976. Catenas in different climates. Geomorphology and Climate. Wiley, London, pp. 137-169.

Olson, K.R., Gennadiyev, A.N., Zhidkin, A.P., Markelov, M.V., Golosov, V.N., Lang, J.M., 2013. Use of magnetic tracer and radio-cesium methods to determine past cropland soil erosion amounts and rates. Catena 104, 103-110. https://doi.org/10.1016/j catena. 2012.10.015.

Orlov, D.S., Biryukova, O.N., Rozanova, M.S., 2004. Revised system of the humus status parameters of soils and their genetic horizons. Eurasian Soil Sci. 8, 798-805.

Pasquini, A.I., Campodonico, V.A., Rouzaut, S., Giampaoli, V., 2017. Geochemistry of a soil catena developed from loess deposits in a semiarid environment, Sierra Chica de Córdoba, central Argentina. Geoderma 295, 53-68. https://doi.org/10.1016/j. geoderma.2017.01.033.

Perel'man, A.I., 1975. Geochemistry of the landscape, 2nd ed. Vysshaya shkola, Moscow, pp. 341.

Phillips, J.D., 2009. Landscape evolution space and the relative importance of geomorphic processes and controls. Geomorphology 3-4, 79-85. https://doi.org/10. 1016/j.geomorph.2009.01.007.

Pla-Pueyo, S., Viseras, C., Candy, I., Soria, J.M., García-García, F., Schreve, D., 2015 Climatic control on palaeohydrology and cyclical sediment distribution in the PlioQuaternary deposits of the Guadix Basin (Betic Cordillera, Spain). Quat. Int. 389, 56-69. https://doi.org/10.1016/j.quaint.2015.04.045.

Prikhod'ko, V.E., Cheverdin, Y.I., Titova, T.V., 2013. Changes in the organic matter forms in chernozems of the Kamennaya Steppe under different land uses, locations, and hydromorphism degrees. Eurasian Soil Sci. 12, 1230-1240. https://doi.org/10.1134/ S1064229313120065.

Protasova, N.A., Shcherbakov, A.P., 2003. Trace elements (Cr, V, Ni, Mn, Zn, Cu, Co, Ti, $\mathrm{Zr}, \mathrm{Ga}, \mathrm{Be}, \mathrm{Ba}, \mathrm{Sr}, \mathrm{B}, \mathrm{I}, \mathrm{Mo}$ ) in Chernozems and gray forest soils of the Central Chernozem Region. ISBN 5-9273-0498-2. Voronezh State University, Voronezh. 368 p. (In Russian).

Pustovoytov, K., Deckers, K., Goldberg, P., 2011. Genesis, age and archaeological significance of a pedosediment in the depression around Tell Mozan, Syria. J. Archaeol. Sci. 4, 913-924. https://doi.org/10.1016/j.jas.2010.11.021.

Remy, C.C., Fouquemberg, C., Asselin, H., Andrieux, B., Magnan, G., Brossier, B. Grondin, P., Bergeron, Y., Talon, B., Girardin, M.P., Blarquez, O., Bajolle, L., Ali, A.A., 2018. Guidelines for the use and interpretation of palaeofire reconstructions based on various archives and proxies. Quat. Sci. Rev. 193, 312-322. https://doi.org/10.1016/ j.quascirev.2018.06.010

Richter, J. L., Burras, C.L., 2017. Human-impacted catenas in North-Central Iowa, United States: Ramifications for soil mapping, in: Soil mapping and process modeling for sustainable land use management, pp. 335-363. https://doi.org/10.1016/B978-0-12805200-6.00011-6.

Roquero, E., Silva, P.G., Goy, J.L., Zazo, C., Massana, J., 2015. Soil evolution indices in fluvial terrace chronosequences from central Spain (Tagus and Duero fluvial basins). Quat. Int. 376, 101-113. https://doi.org/10.1016/j.quaint.2014.11.036.

Royall, D., Kennedy, L., 2016. Historical erosion and sedimentation in two small watersheds of the southern Blue Ridge Mountains, North Carolina, USA. Catena 143, 174-186. https://doi.org/10.1016/j.catena.2016.03.020.

Samonova, O.A., Aseeva, E.N., 2009. Lateral distribution of metals within granulometric fractions of soils in forest catenas (the Smolensk-Moscow upland). Vestnik Moskovskogo Universiteta. Seriya 5: Geografiya 3, 58-65.

Samonova, O.A., Aseyeva, E.N., Kasimov, N.S., 2018. Metals in 1-0.25 mm grain-size fraction in the soils of the mixed forest zone of the Russian plain. J. Geochem Explor. 184, 381-393. https://doi.org/10.1016/j.gexplo.2017.07.020.

Scarciglia, F., Conforti, M., Buttafuoco, G., Robustelli, G., Aucelli, P.P.C., Morrone F., Casuscelli, F., Palumbo, G., 2012. Integrated study of a soil catena in the Turbolo watershed (Calabria, southern Italy): Soil processes, hydrology and geomorphic dynamics. Rendiconti Online Societa Geologica Italiana 21 (PART 2), 1215-1217.

Schaetzl, R.J., 2013. Catenas and soils. Treatise on. Geomorphology 4, 145-158. https:// doi.org/10.1016/B978-0-12-374739-6.00074-9.

Šekularac, N., Tovarović, J.C., Ivanović-Šekularac, J., 2017. Investigating structural stability of historic buildings: a case study of a rampart wall of Hilandar Monastery. Struct. Eng. Int.: IABSE 3, 353-361. https://doi.org/10.2749/ 101686617 X14881937385250.

Semenkov, I.N., Aseeva, E.N., Terskaya, E.V., 2013. Geochemical structure of foreststeppe catenas of a balka drainage area in the Upa River basin. Vestnik Moskovskogo Universiteta. Seriya 5: Geografiya 6, 68-75.

Semenova, L.N., Semenov, Y., 2010. The migration ability of heavy metals in soils as the sensitivity indicator of geosystems. Geography Nat. Res. 2, 116-123. https://doi.org/ 10.1016/j.gnr.2010.06.005.

Shatokhin, I.T., 1991. Typology of the defensive structures of the south-western front of the Belgorod line. Archaeol. Slavic South-East. Voronezh 106-110.

Šilhán, K., Galia, T., Škarpich, V., 2016. Detailed spatio-temporal sediment supply reconstruction using tree roots data. Hydrol. Process. 22, 4139-4153. https://doi.org/ 10.1002/hyp.10923.

Simonov, Yu.G., 1978. Main problems of climatic geomorphology. Prob. Climatic Geomorphol. Vladivostok 6-30 (In Russian).

Solomina, O.N., Matskovskii, V.V., Zhukov, R.S., 2011. The Vologda and Solovki dendrochronological 'chronicles' as a source of information about the climate conditions of the last millennium. Dokl. Earth Sci. 2, 1104-1109. https://doi.org/10.1134/ S1028334X11080071.

Sommer, M., Schlichting, E., 1997. Archetypes of catenas in respect to matter-a concept for structuring and grouping catenas. Geoderma 1-2, 1-33. https://doi.org/10.1016/ S0016-7061(96)00095-X.

Stone, R.P., Hilborn, D., 2000. Universal soil loss equation (USLE). Fact-sheet agricultural engineering (Ministry of Agriculture, Food and Rural Af-fairs), May, 2000. http:// www.omafra.gov.on.ca/english/engineer/facts/00-001.pdf.

Sudnik-Wójcikowska, B., Moysiyenko, I.I., 2008. The floristic differentiation of microhabitats within kurgans in the desert steppe zone of southern Ukraine. Acta Societ. Botanicorum Poloniae 2, 139-147.

Surmach, G.P., 1992. Relief formation, forest-steppe formation, contemporaneous erosion and anti-erosion-preventive arrangements. Volgograd.

Sycheva, S., Glasko, M., Chichagova, O., 2003. Holocene rhythms of soil formation and sedimentation in the Central Russian Upland. Quat. Int. 106, 203-213. https://doi. org/10.1016/S1040-6182(02)00173-8.

Tanasienko, A.A., Yakutina, O.P., Chumbaev, A.S., 2011. Effect of snow amount on runoff, soil loss and suspended sediment during periods of snowmelt in southern West Siberia. Catena 1, 45-51. https://doi.org/10.1016/j.catena.2011.05.004.

Targulian, V.O., Goryachkin, S.V., 2004. Soil memory: Types of record, carriers, hierarchy and diversity. Revista Mexicana de Ciencias Geol. 1, 1-8.

Tetzlaff, D., Birkel, C., Dick, J., Geris, J., Soulsby, C., 2014. Storage dynamics in hydropedological units control hillslope connectivity, runoff generation, and the evolution of catchment transit time distributions. Water Resour. Res. 2, 969-985. https://doi. org /10.1002/2013WR014147.

Thornes, J.B., Brunsden, D., 1977. Geomorphology and time. ISBN-10. 0416800904. Methuen, London, UK.

Ustinov, M.T., 2001. Catenography and ecologo-meliorative estimation of soil cover by transect catena method. Sibirskii Ekologicheskii Zhurnal 3, 285-292.

Vanwalleghem, T., Stockmann, U., Minasny, B., McBratney, A.B., 2013. A quantitative model for integrating landscape evolution and soil formation. J. Geophys. Res. Earth Surf. 2, 331-347. https://doi.org/10.1029/2011JF002296.

Walling, D.E., Golosov, V.N., Panin, A.V., He, Q., 2000. Use of radiocaesium to investigate erosion and sedimentation in areas with high levels of Chernobyl fallout. Tracers Geomorphol. 183-200.

Wang, J., Liu, G., Lu, L., Zhang, J., Liu, H., 2015a. Geochemical normalization and assessment of heavy metals $(\mathrm{Cu}, \mathrm{Pb}, \mathrm{Zn}$, and $\mathrm{Ni}$ ) in sediments from the Huaihe River, Anhui, China. Catena 129, 30-38. https://doi.org/10.1016/j.catena.2015.02.008.

Wang, Y., Yang, L., Kong, L., Liu, E., Wang, L., Zhu, J., 2015b. Spatial distribution, ecological risk assessment and source identification for heavy metals in surface sediments from Dongping Lake, Shandong, East China. Catena 125, 200-205. https:// doi.org/10.1016/j.catena.2014.10.023.

Wei, Y., Jiao, J., Zhao, G., Zhao, H., He, Z., Mu, X., 2016. Spatial-temporal variation and periodic change in streamflow and suspended sediment discharge along the mainstream of the Yellow River during 1950-2013. Catena 140, 105-115. https://doi.org/ 10.1016/j.catena.2016.01.016.

Wischmeier, W.H., Smith, D.D., 1978. Predicting rainfall erosion losses. Agricultural handbook, No 537. Washington.

Wolf, M., Pfennig, B., Krause, P., Flügel, W.A., 2009. Delineation of topographic process entities using SRTM for hydrological modelling. In: $18^{\text {th }}$ World IMACS Congress and MODSIM09 International Congress on modelling and simulation: interfacing modelling and simulation with mathematical and computational sciences, Proceedings, pp. 2021-2027.

Xu, F., Hu, B., Yuan, S., Zhao, Y., Dou, Y., Jiang, Z., Yin, X., 2018. Heavy metals in surface sediments of the continental shelf of the South Yellow Sea and East China Sea: Sources, distribution and contamination. Catena 160, 194-200. https://doi.org/10. 1016/j.catena.2017.09.022

Yermolin, A.L., 2012. The newly revealed of the ancient earthen fortifications in the East Crimea (on the materials of archeological investigations). Nauch. Ved. Belgorod. Gos. Univ. Ser. History, Political Sci. 1, 25-33.

Yoo, K., Weinman, B., Mudd, S.M., Hurst, M., Attal, M., Maher, K., 2011. Evolution of hillslope soils: The geomorphic theater and the geochemical play. Appl. Geochem. 26 (SUPPL), S149-S153. https://doi.org/10.1016/j.apgeochem.2011.03.054.

Zaitsev, Y.P., 2017. Fortifications of the fortress of Ak-Kaya in Central Crimea (Hellenistic and Roman periods), in: Wind blows down the Mount Mithridates. The Bosporos and the Black Sea in Antiquity. Studies Presented to V.P. Tolstikov on the Occasion of his 70th Birthday, pp. 173. (In Russian).

Zemlyanitsky, L.T., 1949. Soil formations on canals near Petrov rampart in the Kamyshinsky area. Pochvovedenie 5, 285-295 (In Russian).

Zhidkin, A.P., Golosov, V.N., Svetlichny, A.A., Pyatkova, A.V., 2015. An assessment of load on the arable slopes on the basis of field methods and mathematic models. Geomorphol. RAS 2, 41-53. https://doi.org/10.15356/0435-4281-2015-2-41-53.

Zolotareva, B.N., Bukhonov, A.V., Demkin, V.A., 2012. The structural state of buried and surface soils of solonetzic complexes in the dry steppe zone of the Lower Volga basin. Eurasian Soil Sci. 7, 690-699. https://doi.org/10.1134/S1064229312010176.

Zolotokrylin, A.N., Kantsebovskaya, I.V., Krenke, A.N., 1992. Regionalization of Russian territory according to the degree of extremes of natural living conditions. Izvestiya Akademiya Nauk. Seriya Geograficheskaya 6, 16-30. 